\title{
Framework and guidelines for conducting risk analyses for alien species
}

\author{
Sabrina Kumschick ${ }^{1,2^{*}}$, John R Wilson ${ }^{1,2}$, Llewellyn C Foxcroft ${ }^{3}$ \\ ${ }^{1}$ Centre for Invasion Biology, Department of Botany \& Zoology, Stellenbosch \\ University, Private Bag X1, Matieland 7602, South Africa \\ ${ }^{2}$ South African National Biodiversity Institute, Kirstenbosch National Botanical \\ Gardens, Claremont 7735, South Africa \\ ${ }^{3}$ Centre for Invasion Biology and Conservation Services, South African National \\ Parks, Private Bag X402, Skukuza 1350, South Africa
}

*corresponding author: sabrinakumschick@sun.ac.za

\begin{abstract}
This report presents a framework for analysing the risk of alien taxa under South Africa's National Environmental Management: Biodiversity Act of 2004, and the Alien and Invasive Species Regulations of 2014. While the report was initially designed to meet a specific South Africa need, the risk analysis processes developed can, we believe, be transferred to any specified geographic region. In outlining a series of questions related to a taxon's likelihood of invasion and the consequences thereof, i.e. the potential impacts, the report provides a structure for collating data relevant to the process of listing taxa as well as a process for developing recommendations that is both mathematically sound, transparent, and that explicitly takes uncertainty into account. The framework is based on collating information according to international standards in biological invasions (specifically the IUCN Environmental Impact Classification of Alien Taxa Scheme, the CBD's scheme for classifying invasion pathways, and the Unified Framework for Biological Invasions proposed by Blackburn et al. 2011). The risk analysis framework is currently being implemented in South Africa in an effort to underpin national regulatory lists of invasive species.
\end{abstract}

Keywords: Risk analysis, risk assessment, biological invasions, regulations, policy, risk management 


\section{Introduction}

Species are being moved around the world by humans (both accidentally and deliberately) in increasing numbers, and in new ways. When introduced to new biogeographical regions, some of these alien taxa establish and spread without further human assistance (i.e. they become invasive). While many alien taxa are highly beneficial, some alien taxa can have significant negative impacts on the recipient environment and socio-economy. In order to deal with such undesirable consequences and to mitigate future impacts, frameworks for the regulation of alien taxa have been developed all over the world. Such regulations often include lists of species for which certain activities are prohibited or restricted. Decisions on these lists require a scientific analysis of risk.

The process of risk analysis is composed of hazard identification, risk assessment, risk management, and risk communication. In the context of alien taxa, the hazard is that an alien species once introduced will either directly or indirectly (e.g. through acting as a vector for parasites) have undesired environmental or socio-economic impacts. Risk assessment consists of assessing the likelihood and consequences of a given alien taxon causing such negative impacts. And risk management deals with options to reduce the risk including within the context of potential benefits. Finally risk communication is about how the information is made accessible (see Annexure 1 for a glossary).

The purpose of this report is to present a framework for the analysis of the risks associated with alien taxa and to provide a structure for collating evidence for listing alien taxa. The report aims to ensure that this process is done in a transparent and repeatable manner that aligns with national and international agreements, policies and best practices.

The risk analysis framework presented here is specifically designed for the purpose of listing alien species under the regulatory framework of the South African National Environmental Management: Biodiversity Act (NEMBA, Act 10 of 2004) Alien and Invasive Species Regulations (hereafter called NEM:BA A\&IS Regulations; Department of Environmental Affairs 2014). The regulations prescribe specific management actions and require cognisance of the benefits to stakeholders. While the risk analysis concepts are imbedded in various scientific literature, we present the applicability and guidance of a practical framework. We also provide guidance on risk scoring (how to assess each point) and determining a confidence score (how confident you are in giving a specific score). Under the NEM:BA A\&IS Regulations, additional information is required to obtain a permit for a category 2 species, and to obtain a permit to import a species, specifically there needs to be information about the restricted activities (e.g. where organisms are to be housed, and what protocols are in place to provide their spread). For details of how the framework aligns with the regulations see Supplementary Material Appendix S0.

\section{Structure of the framework}

The framework is divided into five sections: 1) Background (BAC) provides information on the assessor, the taxon under consideration and information needed to analyse the risk; 2) Likelihood (LIK) assesses biological, ecological and 
behavioural traits of the taxon that could lead to its arrival, establishment and spread; 3) Consequences (IMP) include the recorded and likely impacts of the taxon; 4) Risk management (MAN) includes questions related to the ability to control a taxon in the context of whether the taxon is beneficial in some situations and results in a recommendations for listing taxa; 5) Reporting provides guidance on how to communicate the outcomes of the analysis. Section 2) and 3) together form the Risk assessment, and 4) includes Risk management considerations. All the sections together form the Risk analysis (Figure 1, Table 1).

Figure 1. A schematic of the risk analysis framework described here. For each chapter there are a number of parameters which need to be assessed (see Table 1).

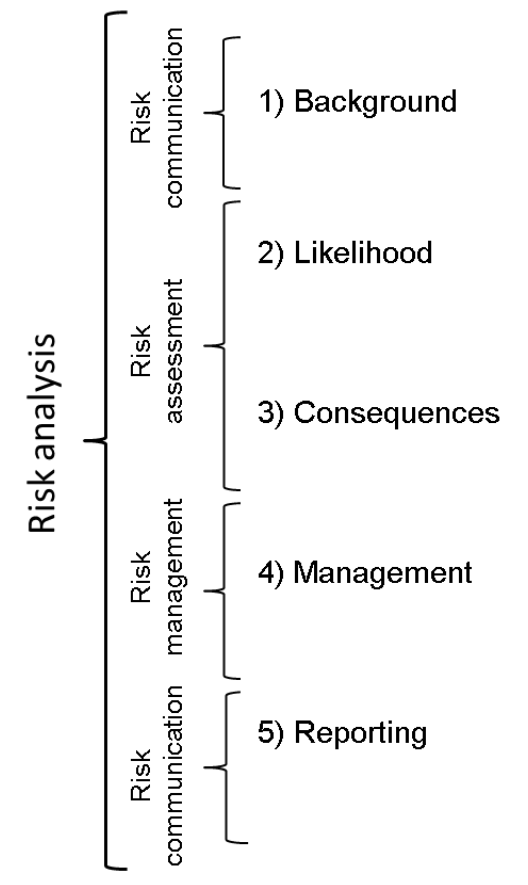

\begin{tabular}{|l|l|l|}
\hline Description & Why? & Parameters \\
\hline $\begin{array}{l}\text { Provides details of what the } \\
\text { analysis is on, and who did the } \\
\text { analysis }\end{array}$ & $\begin{array}{l}\text { To "set the stage" } \\
\text { and ensure } \\
\text { transparency and } \\
\text { repeatability }\end{array}$ & BAC1 - BAC14 \\
\hline $\begin{array}{l}\text { To collate evidence on aspects } \\
\text { which could facilitate entry, } \\
\text { establishment, and spread }\end{array}$ & $\begin{array}{l}\text { To assess the } \\
\text { potential for } \\
\text { establishment and } \\
\text { invasion }\end{array}$ & LIK1 - LIK6 \\
\hline $\begin{array}{l}\text { All evidence of possible } \\
\text { impacts needs to be collated } \\
\text { and scored for environmental } \\
\text { impacts and socio-economic } \\
\text { impacts }\end{array}$ & $\begin{array}{l}\text { To enable } \\
\text { estimation of } \\
\text { current and } \\
\text { potential severity of } \\
\text { impacts }\end{array}$ & IMP1 - IMP5 \\
\hline $\begin{array}{l}\text { Available management options } \\
\text { are assessed which could } \\
\text { mitigate invasiveness and } \\
\text { impacts, and benefits }\end{array}$ & $\begin{array}{l}\text { To get insight into } \\
\text { options for } \\
\text { regulation and } \\
\text { management }\end{array}$ & MAN1-MAN3 \\
\hline $\begin{array}{l}\text { Summarise results of risk } \\
\text { assessment and management } \\
\text { and provide recommendation } \\
\text { for management and regulation }\end{array}$ & $\begin{array}{l}\text { To communicate } \\
\text { results clearly and } \\
\text { ensure objective } \\
\text { interpretation of } \\
\text { assessment }\end{array}$ & \\
\hline
\end{tabular}

Table 1. A list of information needed to complete the risk analysis.

\begin{tabular}{|c|c|c|}
\hline Parameter & Description & Definition and purpose \\
\hline BAC1 & Name of assessor(s) & To identify the person who performed the assessment \\
\hline BAC2 & $\begin{array}{l}\text { Contact details of } \\
\text { assessor(s) }\end{array}$ & $\begin{array}{l}\text { For means of contacting the assessors in case of } \\
\text { questions, further information required, or if the } \\
\text { assessment needs revision }\end{array}$ \\
\hline BAC3 & $\begin{array}{l}\text { Name(s) and contact } \\
\text { details of expert(s) } \\
\text { consulted }\end{array}$ & Identifies experts which were consulted \\
\hline BAC4 & $\begin{array}{l}\text { Scientific name of } \\
\text { Taxon under } \\
\text { assessment }\end{array}$ & $\begin{array}{l}\text { Gives information on the species, sub-species, variety, } \\
\text { genus, or other taxonomic entity under assessment }\end{array}$ \\
\hline BAC5 & Synonym(s) considered & $\begin{array}{l}\text { Information on which synonyms were considered for } \\
\text { the assessment }\end{array}$ \\
\hline BAC6 & $\begin{array}{l}\text { Common name(s) } \\
\text { considered }\end{array}$ & $\begin{array}{l}\text { Information on which common names were } \\
\text { considered for the assessment }\end{array}$ \\
\hline
\end{tabular}




\begin{tabular}{|c|c|c|}
\hline Parameter & Description & Definition and purpose \\
\hline BAC7 & $\begin{array}{l}\text { What is the native range } \\
\text { of the Taxon? }\end{array}$ & $\begin{array}{l}\text { Information on the distribution range of the taxon is I } \\
\text { Important for the assessment as the framework is } \\
\text { designed for alien species specifically }\end{array}$ \\
\hline BAC8 & $\begin{array}{l}\text { What is the global alien } \\
\text { range of the Taxon? }\end{array}$ & $\begin{array}{l}\text { This is crucial as for some questions, only information } \\
\text { in the alien range is considered }\end{array}$ \\
\hline BAC9 & $\begin{array}{l}\text { Geographic scope }=\text { the } \\
\text { Area under } \\
\text { consideration }\end{array}$ & Delimits the assessment area \\
\hline BAC10 & $\begin{array}{l}\text { Is the Taxon present in } \\
\text { the Area? }\end{array}$ & $\begin{array}{l}\text { Crucial for management recommendations (e.g., } \\
\text { prevention vs. control) }\end{array}$ \\
\hline BAC11 & $\begin{array}{l}\text { Availability of physical } \\
\text { specimen }\end{array}$ & $\begin{array}{l}\text { To link the identification of the taxon to a physical } \\
\text { sample, i.e. so that in the future if need be it will be } \\
\text { possible to determine what the Taxon's identity was } \\
\text { compared to at the initial identification. I.e. if it turns out } \\
\text { in future that the identification could be wrong, we } \\
\text { need to be able to understand why it was identified as } \\
\text { that particular Taxon }\end{array}$ \\
\hline BAC12 & $\begin{array}{l}\text { Is the Taxon native to } \\
\text { the Area or part of the } \\
\text { Area? }\end{array}$ & $\begin{array}{l}\text { Important for management as this framework only } \\
\text { deals with alien species }\end{array}$ \\
\hline BAC13 & $\begin{array}{l}\text { What is the Taxon's } \\
\text { introduction status in the } \\
\text { Area? }\end{array}$ & Can aid management decisions \\
\hline BAC14 & $\begin{array}{l}\text { Primary (introduction) } \\
\text { pathways }\end{array}$ & $\begin{array}{l}\text { This information will be used to answer questions on } \\
\text { likelihood of entry }\end{array}$ \\
\hline LIK1 & $\begin{array}{l}\text { Likelihood of entry via } \\
\text { unaided primary } \\
\text { pathways }\end{array}$ & $\begin{array}{l}\text { The probability of the Taxon to arrive and enter an } \\
\text { area without human assistance }\end{array}$ \\
\hline LIK2 & $\begin{array}{l}\text { Likelihood of entry via } \\
\text { human aided primary } \\
\text { pathways }\end{array}$ & $\begin{array}{l}\text { The probability of the Taxon to arrive and enter an } \\
\text { area human aided }\end{array}$ \\
\hline LIK3 & Habitat suitability & Forms part of the likelihood of a Taxon to establish \\
\hline LIK4 & Climate suitability & Forms part of the likelihood of establishment \\
\hline LIK5 & $\begin{array}{l}\text { Unaided secondary } \\
\text { (dispersal) pathways }\end{array}$ & Assesses spread potential \\
\hline LIK6 & $\begin{array}{l}\text { Human aided secondary } \\
\text { (dispersal) pathways }\end{array}$ & Assesses spread potential aided by humans \\
\hline IMP1 & Environmental impact & $\begin{array}{l}\text { Includes impacts caused by the Taxon on the } \\
\text { environment through different mechanisms }\end{array}$ \\
\hline IMP2 & Socio-economic impact & $\begin{array}{l}\text { Includes impacts caused by the Taxon on different } \\
\text { socio-economic sectors }\end{array}$ \\
\hline *IMP3 & $\begin{array}{l}\text { Closely related species' } \\
\text { environmental impact }\end{array}$ & $\begin{array}{l}\text { If no data on the Taxon itself is available, this includes } \\
\text { impacts caused by related taxa on the environment } \\
\text { through different mechanisms }\end{array}$ \\
\hline *IMP4 & $\begin{array}{l}\text { Closely related species' } \\
\text { socio-economic impact }\end{array}$ & $\begin{array}{l}\text { If no data on the Taxon itself is available, this includes } \\
\text { impacts caused by related taxa on different socio- } \\
\text { economic sectors }\end{array}$ \\
\hline IMP5 & Potential impact & $\begin{array}{l}\text { Assesses the potential impact of the Taxon in the Area } \\
\text { if invasive }\end{array}$ \\
\hline
\end{tabular}




\begin{tabular}{|c|l|l|}
\hline Parameter & \multicolumn{1}{|c|}{ Description } & \multicolumn{1}{c|}{ Definition and purpose } \\
\hline \#MAN1 & $\begin{array}{l}\text { What is the feasibility of } \\
\text { stopping future } \\
\text { immigration? }\end{array}$ & $\begin{array}{l}\text { Important for effectiveness of control, as new influx of } \\
\text { propagules needs to be stopped to control the Taxon } \\
\text { effectively and sustainably }\end{array}$ \\
\hline \#MAN2 & Benefits of the Taxon & $\begin{array}{l}\text { Socio-economic and environmental benefits are } \\
\text { included to assess the need of stakeholders for the } \\
\text { Taxon }\end{array}$ \\
\hline \#MAN3 & $\begin{array}{l}\text { Ease of management } \\
\text { Has the feasibility of } \\
\text { eradication been } \\
\text { evaluated? }\end{array}$ & $\begin{array}{l}\text { Tonide indication of how easy the Taxon is to } \\
\text { management decisions. }\end{array}$ \\
\hline $\begin{array}{l}\text { Indicates whether the feasibility of eradicating the } \\
\text { Taxon from the Area has been formally evaluated or } \\
\text { not. Note the evaluation of eradication feasibility is a } \\
\text { separate process to the risk analysis framework. }\end{array}$ \\
\hline
\end{tabular}

*not assessed if IMP1 and IMP2 can be filled in respectively, i.e. information on impact is available for the Taxon

\#not assessed if risk is low for the Taxon 


\section{Scope of assessment}

As the risk analysis performed here is meant so serve as the evidence base for the listing of alien species under the NEMBA A\&IS Regulations, these should not be used as evidence to answer any of the questions. Furthermore, the analysis should not be filled in to fit the current listing category (for taxa already regulated) but should be done independently of these regulations.

The region under assessment is referred to as the Area in the remainder of the document and in the framework (see BAC9). In most cases assessments will be done on the level of a country (in this case South Africa), but the only criterion is that the Area is clearly specified (e.g. it could be a province of South Africa).

The taxon under assessment is referred to as the Taxon (see BAC4-BAC6). The Taxon can be a species, sub-species, genus or any other taxonomic level. Risk analyses are mostly carried out on individual species, but this is not always appropriate, e.g. if the taxonomy of a group is not well resolved; if species are difficult to distinguish but the whole group (i.e., genus or family) is of potential concern (e.g. certain invertebrate plant pests like mites or rust fungi); and if there are important differences between sub-species.

\section{Guidance on scoring risk and confidence}

A thorough literature review on the Taxon should be conducted to find all relevant information. If no information is published on the Taxon, closely related taxa should be considered, for example congeners. If this is the case, it needs to be clearly indicated in the comments of the respective questions where such information was used. Experts on the Taxon should be consulted, especially if the Taxon is data deficient or data are not readily available, including indigenous knowledge where the Taxon is native. Some information can be extracted from national and international databases on native and alien species, e.g. the Global Invasive Species Database, Global Biodiversity Information Facility, and the Red List of Threatened Species. A list of potential sources of information can be found in the Supplementary Material Appendix S1. It is also possible to assess the respective taxa in expert groups, e.g. through workshops and working groups.

Unless otherwise specified, each question should have one answer out of the response options provided (in the Response box on the Answer sheet), with a corresponding estimate of the confidence in the answer (in the Confidence box on the Answer sheet, see Guidance on confidence scoring in Supplementary Material Appendix S2). In each case, a short description on why the Response was chosen must be provided in the Rationale/Comments section on the Answer sheet, including names of experts consulted for the respective questions, a summary of the main sources of information, and citations that were used to help answer the question. It is acceptable to copy and paste information directly from the sources, given these are properly referenced and put in inverted commas. List relevant references used for each question in the References section, providing the full reference including authors, year, title, journal (if applicable), issue and page numbers, and a web-links for websites (e.g. a digital object identifier for books, databases, and journal articles) including date of access, and the name and contact details of experts who provided 
input into specific questions, including links to the databases or information if possible.

The confidence score should give an indication regarding the certainty of the answer, in other words, how confident the assessor is that the answer provided is correct. This generally depends on the amount and quality of data available on the Taxon. Guidance on confidence rating is based on the one described in the EPPO pest risk assessment decision support scheme (Hawkins et al. 2015), and given in the Supplementary Material (Appendix S2).

All these sections are mandatory and have to be filled in.

\section{Data sources}

Some useful data sources to answer certain questions are given in the Supplementary Material Appendix S1. The scientific literature should be taken into account, and primary sources used and cited where possible. However, databases on alien species contain a lot of useful information on many taxa, too. This table is not an inclusive list of all potential sources which can and should be considered for risk analyses, and it does not replace the reference list which needs to be provided by the assessor as support for answering the questions outlined in the framework. 


\section{Risk analysis framework}

The questions are described here in detail. For each question, a section in the Answer sheet needs to be filled in, generally consisting of Response, Confidence, Comments/Rationale, and References. Unless otherwise stated, all these sections need to be filled in.

\section{1) Background}

The background gives important information on the assessor, the Area, and the Taxon.

\section{BAC1 Name of assessor(s)}

Give the full name and surname of the main assessor and any additional assessors. The lead assessor takes responsibility for the assessment and is the author/assessor for correspondence. Add more lines if more assessors were involved.

\section{BAC2 Contact details of assessor(s)}

Add more lines if more assessors were involved.

\section{BAC3 Name(s) and contact details of expert(s) consulted}

This can include internal (within same organisation or group of assessors) or external (including international) experts or reviewers, which influenced, commented or amended the document before submission. In the comments, outline the kind of contribution these experts made. Add additional lines if several experts were consulted.

\section{BAC4 Scientific name of Taxon under assessment}

The biological entity under consideration. The full scientific (binomial) name as well as taxonomic authority is required. In most cases, this will be a species, but it could be another taxonomic level (e.g. genus or sub-species). Mention the taxonomic level under comments. The organism under assessment will be called the "Taxon" in the rest of the document. Check ITIS (http://www.itis.gov/) or a taxon specific taxonomic database for the correct nomenclature, and note the validity of the name under comments. Note in the references which database was used for the species identification/name.

\section{BAC5 Synonym(s) considered}

List synonyms of the scientific (Latin) name of the Taxon which were considered for this assessment. Only list names included in the literature search, not synonyms which were not considered. Check for synonyms in ITIS (http://www.itis.gov/) or a taxon specific taxonomic database. Note in the references which database was considered.

\section{BAC6 Common name(s) considered}

List common names of the Taxon which were considered for this assessment. Only list names included in the literature search, not all recorded common names. In the comments, indicate where the common names are used, and which languages were considered.

\section{BAC7 What is the native range of the Taxon?}

The Taxon's biogeographic distribution provides useful context for understanding the actual and potential range of the Taxon. Here, a description in words is required, which can aid the literature search. If the Taxon's native range includes the Area or part of the Area, see BAC12.

A map of the native range should be provided, if possible. If the map is available in a file, please insert a low res copy $(<1 \mathrm{MB})$ as an appendix to the Answer sheet and provide the file name and (if possible) a link to a higher resolution copy. 


\section{BAC8 What is the global alien range of the Taxon?}

This includes the Taxon's global alien range, including the range within the Area. The distribution of the Taxon's introduced range provides useful context for understanding the actual and potential range of the Taxon and provides guidance for the literature search. For example, we are only interested in negative impacts caused in the alien range for the impact scoring and classification, even though some species also have undesirable effects in the native range under certain conditions.

A map of the alien range should be provided, if possible. If the map is available in a file, please insert a low res copy $(<1 \mathrm{MB})$ as an appendix to the Answer sheet and provide the file name and (if possible) a link to a higher resolution copy.

\section{BAC9 Geographic scope $=$ the Area under consideration}

Specify the geographic entity under consideration, i.e. the geographic scope of the assessment. In most cases this will be the whole of South Africa, but can also be only a part of the country, for example a single province, a national park or a river catchment. The region under assessment will hereafter be referred to as the "Area". The Taxon should generally only be assessed in its alien range.

\section{BAC10 Is the Taxon present in the Area?}

Note if the Taxon is present anywhere in the Area. In the case where the presence of the species is not confirmed but a record has been noted, include field visits, as appropriate.

\section{BAC11 Availability of physical specimen}

In the Response, state if a physical sample was collected in the Area (yes/no). The name of the herbarium/museum and its accession number / record of the Taxon in the Area should be provided in the respective section. The record should have been checked by a national and/or international taxonomic expert, and the person at the herbarium/museum who identified the sample and date should also be given.

If the Taxon has not previously been reported as present in the Area and the identity is not certain OR if no herbarium or museum record is available, contact a relevant specialist. Record all information that can be obtained from the specialist; including a reference to some herbarium or museum, so that in the future if need be it will be possible to determine what the Taxon's identity was compared to at the initial identification, i.e. if it turns out in future that the identification could be wrong, we need to be able to understand why it was identified as that particular Taxon.

\section{BAC12 Is the Taxon native to the Area or part of the Area?}

Indicate whether the Taxon is native or alien and select one of the answers provided for each (yes, no, or don't know). If native to parts of the Area, specify its native and alien range in the Comments. If alien to the whole or parts of the Area, clarify under BAC7 that only alien ranges are considered for this assessment. If the Taxon is native to the whole of the Area, it should not be considered for listing under the NEMBA Regulations in that Area and does not go through the assessment process. For species native to the mainland but alien on the off-shore islands, listing should only be considered for the islands, i.e. the Area (as specified under BAC7) should be the islands.

\section{BAC13 What is the Taxon's introduction status in the Area?}

If the Taxon is present in the Area, define its introduction status as follows (according to Blackburn et al. 2011; described in more detail in Supplementary Material Appendix S4):

- alien in cultivation/captivity: individuals transported beyond the limits of its native range and in captivity, quarantine or cultivation, i.e., individuals provided with conditions suitable for them, but explicit measures of containment or explicit measures to prevent spread are in place

- alien outside of cultivation/captivity: individuals transported beyond the limits of native range and directly released into the new environment, or individuals escaped from cultivation/captivity, but incapable of surviving for a significant period or, if surviving in the wild, no reproduction or, if reproduction occurring, population not self-sustaining

- established: individuals surviving outside of cultivation/captivity in locations where introduced, reproduction occurring, and population self-sustaining

- invasive: self-sustaining populations outside of cultivation/captivity with individuals surviving and reproducing a significant distance from the original point of introduction, i.e. dispersal happening. Give information on each step in the invasion continuum and select one of the answers provided for each (yes, no, or don't know). 


\section{BAC14 Primary (introduction) pathways}

List historical, currently known and potential future entry pathways for the Taxon in the Area and other introduced ranges. The pathway classification is based on the one accepted by the Convention on Biological Diversity (CBD), and is given in Appendix S3 (modified from Essl et al. 2011). Provide information on all categories and, if available, on the sub-categories in the Response.

\section{2) Likelihood}

This section deals with the likelihood of the Taxon to enter (LIK1 \& LIK2), establish (LIK3 \& LIK4) and spread (LIK5 \& LIK6) in the Area, which is representing the steps alien taxa need to take in order to become invasive. This section therefore assesses the likelihood of the Taxon to become invasive.

All the answers are described in scenarios for each level separately, with each level being an order of magnitude more likely than the next lower level. If the answer is unknown, it is set as $p=1$ due to the precautionary principle (i.e., a high likelihood is assumed if not known).

Generally, all the answers in this section are structured in the same way, and they follow the logic described here:

- Extremely unlikely $(p=0.000001)$ : less likely than winning the lottery if you play it once

- Very unlikely $(p=0.0027)$ : less likely than a new person you meet having their birthday on the same day as yours

- Unlikely $(p=0.027)$ : less likely than rolling 2 sixes when playing dice

- Fairly probable $(p=0.5)$ : less likely than getting heads when flipping a coin, i.e., fifty-fifty

- Probable $(p=1)$ : more likely than fifty-fifty (it is likely to happen in more than 5 times out of 10)

The probability levels $p$ represent the likelihood of an event happening, and will be used to calculate a final likelihood of an invasion to occur (see Figure 2 and Table 2).

The questions in this section represent the invasion process, with two questions for each step in the process (i.e., entry, establishment, and spread). Each answer to the questions in this section is attached to a probability value $p$ as indicated in brackets in the response options (i.e., Extremely unlikely: $p=0.000001$; Very unlikely: $p=$ 0.0027; Unlikely: $p=0.027$; Fairly probable: $p=0.5$; Probable: $p=1$; Don't know: $p=$ 1).

Figure 2 illustrates how to calculate a final Likelihood score from the answers provided in LIK1-LIK6. Subsequently, this value can be transcribed into a Likelihood description as in Table 2, which feeds into the Risk assessment (Table 3). 


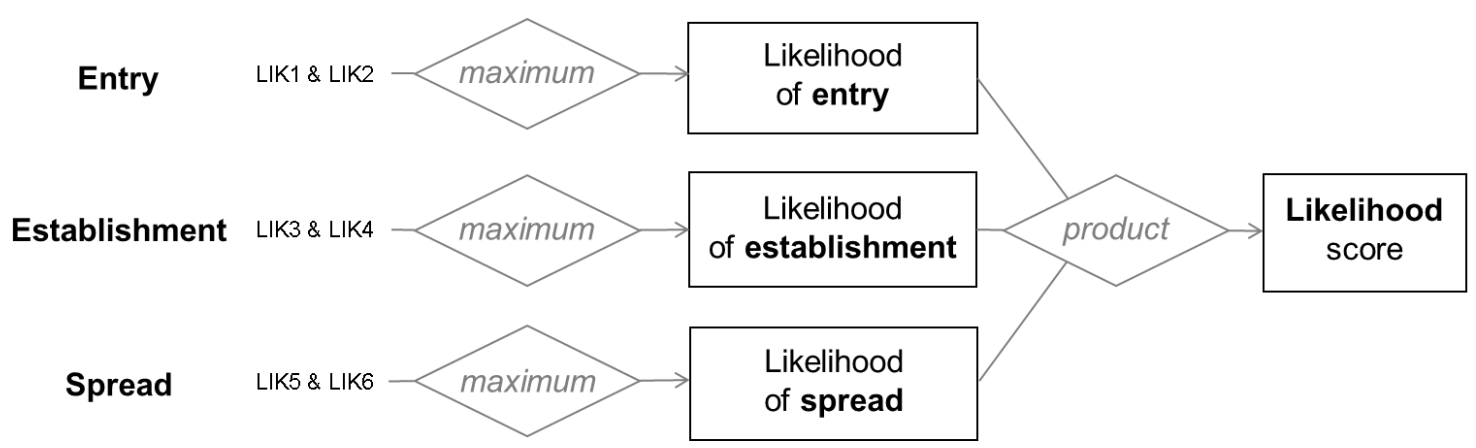

Figure 2 The calculation of a final likelihood score from the likelihood questions LIK1-LIK6. The likelihood descriptions to extract a Risk score for the Risk assessment in Table 3 can then be found in Table 2.

Table 2: Transcription of Likelihood scores into descriptions for the Risk score in Table 3. The Likelihood score is calculated as in Figure 2.

\begin{tabular}{|l|l|}
\hline Likelihood score & Likelihood (description) \\
\hline$<0.000001$ & Extremely unlikely \\
\hline $0.000001 \leq p<0.0027$ & Very unlikely \\
\hline $0.0027 \leq p<0.027$ & Unlikely \\
\hline $0.027 \leq p<0.5$ & Fairly probable \\
\hline$p \geq 0.5$ & Probable \\
\hline
\end{tabular}

\section{LIK1 Likelihood of entry via unaided primary pathways}

If the Taxon is present in the Area (see BAC10), the probability of entry should be set as 1 . Still fill in this section as if the Taxon was not present and give details on pathways, as this can inform risk management and the feasibility to stop future immigration. However for the calculations, use the probability of 1 .

Estimate the probability that the Taxon enters the Area from outside the Area through unaided pathways within the timespan of a decade. Consider the unaided pathways mentioned under BAC 14. Features of the Taxon which favour unaided entry include presence in neighbouring countries and regions, water or wind dispersed propagules (e.g. floating propagules), the ability to fly long distances, the ability for fish to move from one river catchment where introduced, to another via connected waterways. Animal dispersal is also considered here, except domestic and farm animals which are included under LIK2. The following factors can aid entry via animals: edible parts (e.g. fruits) which are eaten by animals, propagules with spines/barbs/sticky substances which can attach to animals, very small propagules which can get stuck in fur and feathers, pests attached to plants or animals. List the pathways and corresponding likelihoods in the comments section. In the response, give the highest likelihood for any pathway. The assessment should be based on the likelihood of entry based on current and future pathways.

\section{Response options:}

Extremely unlikely $(p=0.000001)$ : the Taxon and its propagules are highly sessile and are known never to disperse on its own - proof is required for inability to move, otherwise classify as "Very unlikely".

Very unlikely $(p=0.0027)$ : the Taxon and its propagules are sessile and do not usually disperse on their own

Unlikely $(p=0.027)$ : the Taxon is sessile, but it can disperse during one specific life stage, dispersal capabilities are slow and short distance

Fairly probable $(p=0.5)$ : the Taxon is highly mobile during at least one of its life stages and can reach a high dispersal capability during one of its life stages 
Probable $(p=1)$ : highly mobile Taxon with dispersal capability fast and over large distances Don't know $(p=1)$ : no information is available on the unaided pathways available to the Taxon

\section{LIK2 Likelihood of entry via human aided primary pathways}

If the Taxon is present in the Area (see BAC10), the probability of entry should be set as 1 . Still fill in this section as if the Taxon was not present and give details on pathways, as this can inform risk management and the feasibility to stop future immigration. However for the calculations, use the probability of 1 .

Estimate the probability that the Taxon enters the Area from outside the Area through the pathways mentioned under BAC14 which are human mediated (as opposed to unaided, which are covered in LIK1) within the timespan of a decade. List the pathways and corresponding likelihoods in the comments section. This also includes entry from neighbouring countries (consider it could in future be introduced into neighbouring countries). In the response, give the highest likelihood for any pathway. The assessment should be based on the likelihood of introductions based on current and future pathways. For taxa which are already present in the Area, mainly focus on unintentional pathways.

\section{Response options:}

Extremely unlikely $(p=0.000001)$ : There is currently no human aided entry pathway available/in use for the Taxon, and no future pathway is expected to arise

Very unlikely $(p=0.0027)$ : There is currently a human aided entry pathway available/in use, but the Taxon is highly sensitive to movement and is unlikely to arrive alive at any life stage

Unlikely $(p=0.027)$ : There is a human aided entry pathway available/in use which is infrequently used, and/or future new pathways are expected to arise; also, the Taxon is not expected to arrive in high numbers

Fairly probable $(p=0.5)$ : Several human aided entry pathways are available/in use but not regularly used, and/or some potentially lead to a high number of introductions

Probable $(p=1)$ : Several human aided entry pathways available and regularly used for the Taxon, and high numbers of individuals expected.

Don't know $(p=1)$ : no information is available on the human aided pathways used by the Taxon

\section{LIK3 Habitat suitability}

Indicate the likelihood of the Taxon to find suitable habitats in the Area for survival and reproduction. Habitat includes the presence of suitable food items, hosts, pollinators, seed dispersers, and other biotic conditions. If the Area encompasses multiple habitats, consider those that are most likely suited and mention in the comments section which habitats were assessed. Thus also take the habitat specificity of the Taxon into account. Artificial habitats include for example (with increasing degree of artificiality) gardens, zoos, greenhouses, indoor habitats.

\section{Response options:}

Extremely unlikely $(\mathrm{p}=<0.000001)$ : the Taxon is extremely specialised and there is no suitable habitat in the Area, none of the key conditions for the Taxon's survival are met

Very unlikely ( $p=0.0027$ ): the Taxon is highly specialised, but there is reason to assume that it might adapt to some biotic habitat conditions; only highly artificial habitats which are rare or difficult to maintain are suitable.

Unlikely $(p=0.027)$ : the Area provides habitat that is only partly suitable to the Taxon; certain artificial habitats are suitable

Fairly probable $(p=0.5)$ : the key conditions are met, but only in a marginal part of the Area; also nonartificial habitats suitable.

Probable $(p=1)$ : all key biotic habitat conditions are met in a large part of the Area.

Don't know $(p=1)$ : no information is available on habitat requirements of the Taxon

\section{LIK4 Climate suitability}

Indicate the likelihood of the Taxon to find suitable climate in the Area for survival and reproduction. Use the native and alien ranges as references for the Taxon's distribution, as obtained in BAC7 and BAC8. As a minimal standard, use published maps of climate zones to check whether the climate in the Area is suitable for the Taxon. Such maps include the following:

- Koeppen-Geiger climate zones, updated by Peel et al. (2007)

- Richardson and Thuiller (2007) maps of global locations that match South African climates 
Climate models are more desirable and lead to a higher confidence in the assessment. If the Area encompasses multiple climate zones, consider those that are most likely suited and mention in the comments section which climatic zones were assessed. For species already present in the Area, the answer cannot be "extremely unlikely".

\section{Response options:}

Extremely unlikely $(p=0.000001)$ : The Area provides no suitable climate (including artificially created environments)

Very unlikely ( $p=0.0027)$ : The Area provides no suitable climate, but suitable climate can be artificially created in small $(<5 \%)$ parts of the Area.

Unlikely $(p=0.027)$ : The Area provides little $(<5 \%)$ climatic overlap with the known distribution of the Taxon, excluding artificially created suitable habitats.

Fairly probable $(p=0.5)$ : The main climatic requirements are met in a marginal $(>5 \%$ but $<20 \%-$ one fifth) part of the Area.

Probable $(p=1)$ : The main climatic requirements are met in a larger part $(>20 \%)$ of the Area.

Don't know $(p=1)$ : no information is available on the climatic requirements of the Taxon

\section{LIK5 Unaided secondary (dispersal) pathways}

This includes the unaided pathways currently or potentially bringing the Taxon from the occupied regions to elsewhere within the Area. It excludes unaided pathways bringing propagules from areas outside of the Area into the Area (covered in LIK1). Indicate the probability that the Taxon disperses naturally from a population within the Area to currently unoccupied regions and habitats. Mention details of the expected dispersal pathways and mechanisms in the comments section. More precisely, try to estimate the probability that the Taxon can disperse $>50 \mathrm{~km}$ in a decade. Features of the Taxon which favour unaided dispersal include water or wind dispersed propagules (e.g. floating propagules), the ability to fly long distances, the ability for fish to move from one river catchment where introduced, to another via connected waterways. Animal dispersal is also considered here, except domestic and farm animals which are included under LIK6. The following factors can aid dispersal by animals: edible parts (e.g. fruits) which are eaten by animals, propagules with spines/barbs/sticky substances which can attach to animals, very small propagules which can get stuck in fur and feathers, pests attached to plants or animals.

\section{Response options:}

Extremely unlikely $(p=0.000001)$ : the Taxon and its propagules are highly sessile and are known never to disperse on their own - proof is required for inability to move, otherwise classify as "Very unlikely".

Very unlikely $(p=0.0027)$ : the Taxon and its propagules are sessile and do not usually disperse on their own

Unlikely ( $p=0.027)$ : the Taxon is sessile, but it can disperse during one specific life stage, dispersal capabilities are slow and short distance $(<50 \mathrm{~km}$ in 10 years)

Fairly probable $(p=0.5)$ : the Taxon is mobile and can reach a high dispersal capability during one of its life stages

Probable $(p=1)$ : highly mobile Taxon with dispersal capability fast and over large distances

Don't know $(p=1)$ : no information is available on unaided dispersal pathways used by the Taxon

\section{LIK6 Human aided secondary (dispersal) pathways}

This includes the human aided pathways currently or potentially bringing the Taxon from the occupied regions and habitats elsewhere within the Area. This question does not include dispersal from outside of the Area to the Area as this is covered in LIK2. Indicate the probability that the Taxon gets dispersed from a population within the Area to uninvaded habitats. Intentional and unintentional pathways need to be considered. Mention details of the expected pathways in the comments section. The likelihood score relates to the proximity of the Taxon to human and domestic/farm animals and frequency of contact, which allows it to be dispersed in these kinds of dispersal pathways, as well as traits and features of the Taxon which facilitate for it to be moved around.

More precisely, try to estimate the probability that human-mediated dispersal takes (propagules of) the Taxon $>50 \mathrm{~km}$ in a decade.

Features of the Taxon which favour human aided dispersal include edible parts (e.g. fruits), propagules with spines/barbs/sticky substances which can attach to clothing, vehicles and boats, building materials, very small propagules which can get stuck in clothing/shoes or with movement of 
ornamental plants and be transported unnoticed. Dispersal by domestic and farm animals is included here.

Response options:

Extremely unlikely $(p=0.000001)$ : the Taxon is not present in places accessible by humans, domestic and/or farm animals

Very unlikely $(p=0.0027)$ : the Taxon is only present in places humans, domestic and/or farm animals can reach with difficulty, and/or has no features which make it likely to be dispersed human aided

Unlikely $(p=0.027)$ : the Taxon is present in places where humans, domestic and/or farm animals occasionally occur, and/or has features which make it possible to be dispersed human aided, but only exceptional cases

Fairly probable $(p=0.5)$ : the Taxon is present in places easily accessible by humans and/or it or its propagules are easily moved, i.e. it possesses some feature mentioned above

Probable $(p=1)$ : the Taxon is present in a place frequented by humans, and it or its propagules are easily and regularly moved due to features mentioned above

Don't know $(p=1)$ : no information is available on the human aided pathways used by the Taxon

\section{3) Consequences}

In this section, all evidence of impacts in the global alien range (including the Area) available for the Taxon needs to be collated and scored for environmental impacts and socio-economic impacts. Data on the impacts of the Taxon itself from the Area or other alien regions are the most desirable (IMP1a)-k) and IMP2a)-f)). Only if no data are available on the Taxon in any alien range globally should it be classified as Data Deficient (DD) under IMP1 and IMP2.

If this is the case, i.e. no data are available for the Taxon on impacts anywhere in its global alien range, look for data of congeners or other closely related species with similar life history traits and fill in IMP3 and IMP4.

Additionally consider data in the native range of the Taxon, and/or estimate the magnitude of impact possible for the Taxon in the Area based on biological, ecological and behavioural traits in IMP5. This needs to be filled in regardless of whether information on IMP1 and IMP2 is available, but can lead to similar results if the impact of the Taxon has been well studied.

The environmental impact (IMP1) is based on the Environmental Impact Classification of Alien Taxa (EICAT) system by Blackburn et al. (2014), Hawkins et al. (2015), and the socio-economic rating (IMP2) based partly on the Generic Impact Scoring System (GISS) by Kumschick et al. (2015) and Nentwig et al. (2016).

Due to the lack of comprehensive impact studies for most species in many regions, the assessment of consequences includes information on impact available from the literature in the Area and other alien ranges of the Taxon (IMP1 and IMP2). Additionally, if no data is available on impact for the Taxon, information of closely related species is included (IMP3 and IMP4). These measures (IMP1-4 respectively) give the currently recorded evidence of impact. For a measure of future potential and currently unrecorded impact of the Taxon in the Area, IMP5 includes considerations on the Taxon's traits, behaviour and ecology and considers impacts recorded in the native range.

Fill all results as described below from IMP1-5 into Figure 3 below and in the answer sheet to calculate maximum impact levels for the Taxon. For the consequence score, 
the maximum impact level should be taken between all the impact measures (IMP15). This impact level is then used to calculate the risk score as described in Table 3.

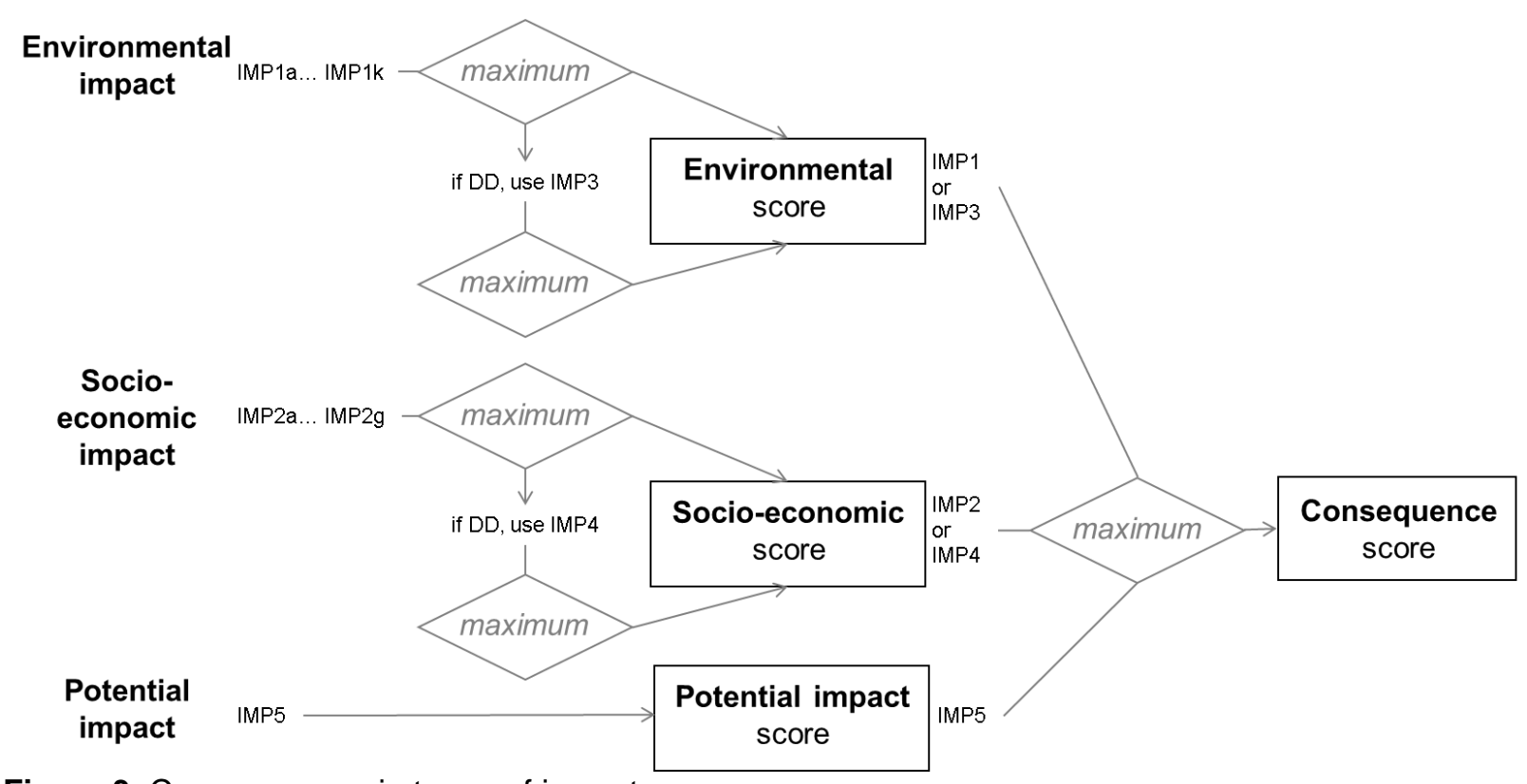

Figure 3: Consequences in terms of impact scores

\section{IMP1 Environmental impact}

The consequence assessment is based on the Environmental Impact Classification of Alien Taxa (EICAT) scheme. EICAT classifies taxa into minimal concern (MC), minor (MN), moderate (MO), major (MR), massive (MV) according to the magnitude of impact they cause. Detailed descriptions of all the impact levels are given in IMP1a)-IMP1k) below.

Fill in the Answer sheet for each of the mechanisms as described below (IMP1a-IMP1k). Then use the scheme provided in Figure 3 to calculate the environmental impact score (IMP1), which is basically the maximum of all the mechanisms. Report on the maximum impact found in any of the mechanisms for the global alien range in the Response for IMP1, and the main mechanism affected in the Rationale, but provide information on all the sectors and impact scores in IMP1a)-IMP1k), including detailed information on the references used for the assessments. If impact assessments have been conducted previously for the Taxon and are available in the literature, information can be extracted from there and no detailed search is needed.

If no data on impact are available for the Taxon anywhere in the global alien range for any of the mechanisms described, mark the Taxon as Data Deficient (DD) here and additionally fill in IMP3, i.e. consider information on closely related taxa. 


\section{IMP1a Competition}

What is the evidence in the global alien range of the Taxon for impact through competition? Does the Taxon compete with native taxa for resources (e.g. food, water, space), leading to deleterious impact on native taxa somewhere in its global alien range?

Classify the Taxon in an impact level according to the descriptions below. If no data is available, the Response is Data Deficient (DD).

\begin{tabular}{|c|c|c|c|c|}
\hline Massive (MV) & Major (MR) & Moderate (MO) & Minor (MN) & $\begin{array}{l}\text { Minimal Concern } \\
\text { (MC) }\end{array}$ \\
\hline $\begin{array}{l}\text { Competition resulting } \\
\text { in replacement or } \\
\text { local extinction of } \\
\text { one or several native } \\
\text { species; changes in } \\
\text { community } \\
\text { composition are } \\
\text { irreversible }\end{array}$ & $\begin{array}{l}\text { Competition } \\
\text { resulting in local or } \\
\text { population } \\
\text { extinction of at least } \\
\text { one native species, } \\
\text { leading to changes } \\
\text { in community } \\
\text { composition, but } \\
\text { changes are } \\
\text { reversible when the } \\
\text { alien taxon is } \\
\text { removed }\end{array}$ & $\begin{array}{l}\text { Competition } \\
\text { resulting in a } \\
\text { decline of } \\
\text { population size of at } \\
\text { least one native } \\
\text { species, but no } \\
\text { changes in } \\
\text { community } \\
\text { composition }\end{array}$ & $\begin{array}{l}\text { Competition affects } \\
\text { fitness (e.g., growth, } \\
\text { reproduction, } \\
\text { defence, } \\
\text { immunocompetence) } \\
\text { of native individuals } \\
\text { without decline of } \\
\text { their populations }\end{array}$ & $\begin{array}{l}\text { Negligible level of } \\
\text { competition with } \\
\text { native species; } \\
\text { reduction of fitness } \\
\text { of native } \\
\text { individuals is not } \\
\text { detectable }\end{array}$ \\
\hline
\end{tabular}

\section{IMP1b Predation}

This consists of the Taxon preying on native taxa somewhere in its global alien range, and includes direct and indirect effects (e.g. via mesopredator release), leading to deleterious impact on native taxa.

Classify the Taxon in an impact level according to the descriptions below. If no data is available, the Response is Data Deficient (DD).

\begin{tabular}{|c|c|c|c|c|}
\hline Massive (MV) & Major (MR) & Moderate (MO) & Minor (MN) & $\begin{array}{l}\text { Minimal Concern } \\
(\mathrm{MC})\end{array}$ \\
\hline $\begin{array}{l}\text { Predators directly or } \\
\text { indirectly (e.g., via } \\
\text { mesopredator } \\
\text { release) resulting in } \\
\text { replacement or local } \\
\text { extinction of one or } \\
\text { several native } \\
\text { species (i.e., } \\
\text { species vanish from } \\
\text { communities at } \\
\text { sites where they } \\
\text { occurred before the } \\
\text { alien arrived); } \\
\text { changes in } \\
\text { community } \\
\text { composition are } \\
\text { irreversible }\end{array}$ & $\begin{array}{l}\text { Predators directly or } \\
\text { indirectly (e.g., via } \\
\text { mesopredator } \\
\text { release) resulting in } \\
\text { local or population } \\
\text { extinction of at least } \\
\text { one native species, } \\
\text { leading to changes } \\
\text { in community } \\
\text { composition, but } \\
\text { changes are } \\
\text { reversible when the } \\
\text { alien taxon is } \\
\text { removed }\end{array}$ & $\begin{array}{l}\text { Predators directly or } \\
\text { indirectly (e.g., via } \\
\text { mesopredator } \\
\text { release) resulting in } \\
\text { a decline of } \\
\text { population size of at } \\
\text { least one native } \\
\text { species but no } \\
\text { changes in } \\
\text { community } \\
\text { composition }\end{array}$ & $\begin{array}{l}\text { Predators directly or } \\
\text { indirectly (e.g., via } \\
\text { mesopredator } \\
\text { release) affecting } \\
\text { fitness (e.g., growth, } \\
\text { reproduction) of } \\
\text { native individuals } \\
\text { without decline of } \\
\text { their populations }\end{array}$ & $\begin{array}{l}\text { Negligible level of } \\
\text { predation on native } \\
\text { species }\end{array}$ \\
\hline
\end{tabular}




\section{IMP1c Hybridisation}

The Taxon hybridises with native species somewhere in its global alien range, leading to deleterious impact on native species.

Classify the Taxon in an impact level according to the descriptions below. If no data is available, the Response is Data Deficient (DD).

\begin{tabular}{|c|c|c|c|c|}
\hline Massive (MV) & Major (MR) & Moderate (MO) & Minor (MN) & $\begin{array}{l}\text { Minimal Concern } \\
\text { (MC) }\end{array}$ \\
\hline $\begin{array}{l}\text { Hybridisation } \\
\text { between the alien } \\
\text { taxon and native } \\
\text { species is common } \\
\text { in the wild; hybrids } \\
\text { are fully vigorous } \\
\text { and fertile; pure } \\
\text { native species } \\
\text { cannot be } \\
\text { recovered by } \\
\text { removing the alien, } \\
\text { resulting in } \\
\text { replacement or local } \\
\text { extinction of native } \\
\text { species by } \\
\text { introgressive } \\
\text { hybridisation } \\
\text { (genomic extinction) }\end{array}$ & $\begin{array}{l}\text { Hybridisation } \\
\text { between the alien } \\
\text { taxon and native } \\
\text { species is common } \\
\text { in the wild; F1 } \\
\text { hybrids are vigorous } \\
\text { and fertile, however } \\
\text { offspring of F1 } \\
\text { hybrids are weak } \\
\text { and sterile (hybrid } \\
\text { breakdown), thus } \\
\text { limited gene flow } \\
\text { between alien and } \\
\text { natives; individuals } \\
\text { of the alien taxon } \\
\text { and hybrids } \\
\text { discernible from } \\
\text { pure natives, pure } \\
\text { native populations } \\
\text { can be recovered } \\
\text { by removing the } \\
\text { alien and hybrids. }\end{array}$ & $\begin{array}{l}\text { Hybridisation } \\
\text { between the alien } \\
\text { taxon and native } \\
\text { species is regularly } \\
\text { observed in the } \\
\text { wild; hybrids are } \\
\text { vigorous, but sterile } \\
\text { (reduced hybrid } \\
\text { fertility),limited gene } \\
\text { flow between alien } \\
\text { and natives, local } \\
\text { decline of } \\
\text { populations of pure } \\
\text { native species, but } \\
\text { pure native species } \\
\text { persists }\end{array}$ & $\begin{array}{l}\text { Hybridisation } \\
\text { between the alien } \\
\text { taxon and native } \\
\text { species is observed } \\
\text { in the wild, but rare; } \\
\text { hybrids are weak } \\
\text { and never reach } \\
\text { maturity (reduced } \\
\text { hybrid viability), no } \\
\text { decline of pure } \\
\text { native populations }\end{array}$ & $\begin{array}{l}\text { No hybridisation } \\
\text { between the alien } \\
\text { taxon and native } \\
\text { species observed in } \\
\text { the wild (prezygotic } \\
\text { barriers), } \\
\text { hybridisation with a } \\
\text { native species } \\
\text { might be possible in } \\
\text { captivity }\end{array}$ \\
\hline
\end{tabular}

\section{IMP1d Transmission of disease}

The Taxon transmits diseases to native species somewhere in its global alien range, leading to deleterious impact on native species.

Classify the Taxon in an impact level according to the descriptions below. If no data is available, the Response is Data Deficient (DD).

\begin{tabular}{|c|c|c|c|c|}
\hline Massive (MV) & Major (MR) & Moderate (MO) & Minor (MN) & $\begin{array}{l}\text { Minimal Concern } \\
\text { (MC) }\end{array}$ \\
\hline $\begin{array}{l}\text { Transmission of } \\
\text { diseases to native } \\
\text { species resulting in } \\
\text { replacement or local } \\
\text { extinction of native } \\
\text { species (i.e., } \\
\text { species vanish from } \\
\text { communities at } \\
\text { sites where they } \\
\text { occurred before the } \\
\text { alien arrived); } \\
\text { changes in } \\
\text { community } \\
\text { composition are } \\
\text { irreversible }\end{array}$ & $\begin{array}{l}\text { Transmission of } \\
\text { diseases to native } \\
\text { species resulting in } \\
\text { local or population } \\
\text { extinction of at least } \\
\text { one native species, } \\
\text { leading to changes } \\
\text { in community } \\
\text { composition, but } \\
\text { changes are } \\
\text { reversible when the } \\
\text { alien taxon is } \\
\text { removed }\end{array}$ & $\begin{array}{l}\text { Transmission of } \\
\text { diseases to native } \\
\text { species resulting in } \\
\text { a decline of } \\
\text { population size of at } \\
\text { least one native } \\
\text { species, but no } \\
\text { changes in } \\
\text { community } \\
\text { composition }\end{array}$ & $\begin{array}{l}\text { Transmission of } \\
\text { diseases to native } \\
\text { species affects } \\
\text { fitness (e.g., growth, } \\
\text { reproduction, } \\
\text { defence, } \\
\text { immunocompetence) } \\
\text { of native individuals } \\
\text { without decline of } \\
\text { their populations }\end{array}$ & $\begin{array}{l}\text { The alien taxon is } \\
\text { not a host of } \\
\text { diseases } \\
\text { transmissible to } \\
\text { native species or } \\
\text { very low level of } \\
\text { transmission of } \\
\text { diseases to native } \\
\text { species; reduction } \\
\text { of fitness of native } \\
\text { individuals is not } \\
\text { detectable }\end{array}$ \\
\hline
\end{tabular}




\section{IMP1e Parasitism}

The Taxon parasitizes native species somewhere in its global alien range, leading directly or indirectly (e.g. through apparent competition) to deleterious impact on natives.

Classify the Taxon in an impact level according to the descriptions below. If no data is available, the Response is Data Deficient (DD).

\begin{tabular}{|c|c|c|c|c|}
\hline Massive (MV) & Major (MR) & Moderate (MO) & Minor (MN) & $\begin{array}{l}\text { Minimal Concern } \\
\text { (MC) }\end{array}$ \\
\hline $\begin{array}{l}\text { Parasites or } \\
\text { pathogens directly } \\
\text { or indirectly (e.g., } \\
\text { apparent } \\
\text { competition) } \\
\text { resulting in } \\
\text { replacement or local } \\
\text { extinction of one or } \\
\text { several native } \\
\text { species (i.e., } \\
\text { species vanish from } \\
\text { communities at } \\
\text { sites where they } \\
\text { occurred before the } \\
\text { alien arrived); } \\
\text { changes in } \\
\text { community } \\
\text { composition are } \\
\text { irreversible }\end{array}$ & $\begin{array}{l}\text { Parasites or } \\
\text { pathogens directly } \\
\text { or indirectly (e.g., } \\
\text { apparent } \\
\text { competition) } \\
\text { resulting in local or } \\
\text { population } \\
\text { extinction of at least } \\
\text { one native species, } \\
\text { leading to changes } \\
\text { in community } \\
\text { composition, but } \\
\text { changes are } \\
\text { reversible when the } \\
\text { alien taxon is } \\
\text { removed }\end{array}$ & $\begin{array}{l}\text { Parasites or } \\
\text { pathogens directly } \\
\text { or indirectly (e.g., } \\
\text { apparent } \\
\text { competition) } \\
\text { resulting in a } \\
\text { decline of } \\
\text { population size of at } \\
\text { least one native } \\
\text { species but no } \\
\text { changes in } \\
\text { community } \\
\text { composition }\end{array}$ & $\begin{array}{l}\text { Parasites or } \\
\text { pathogens directly or } \\
\text { indirectly (e.g., } \\
\text { apparent } \\
\text { competition) affecting } \\
\text { fitness (e.g., growth, } \\
\text { reproduction, } \\
\text { defence, } \\
\text { immunocompetence) } \\
\text { of native individuals } \\
\text { without decline of } \\
\text { their populations }\end{array}$ & $\begin{array}{l}\text { Negligible level of } \\
\text { parasitism or } \\
\text { disease incidence } \\
\text { (pathogens) on } \\
\text { native species, } \\
\text { reduction of fitness } \\
\text { of native } \\
\text { individuals is not } \\
\text { detectable }\end{array}$ \\
\hline
\end{tabular}

\section{IMP1f Poisoning/toxicity}

The Taxon is toxic, or allergenic by ingestion somewhere in its global alien range, inhalation or contact to wildlife, or allelopathic to plants, leading to deleterious impact on native species. Classify the Taxon in an impact level according to the descriptions below. If no data is available, the Response is Data Deficient (DD).

\begin{tabular}{|c|c|c|c|c|}
\hline Massive (MV) & Major (MR) & Moderate (MO) & Minor (MN) & $\begin{array}{l}\text { Minimal Concern } \\
\text { (MC) }\end{array}$ \\
\hline $\begin{array}{l}\text { The alien taxon is } \\
\text { toxic/allergenic by } \\
\text { ingestion, } \\
\text { inhalation, or } \\
\text { contact to wildlife or } \\
\text { allelopathic to } \\
\text { plants, resulting in } \\
\text { replacement or local } \\
\text { extinction of native } \\
\text { species; changes in } \\
\text { community } \\
\text { composition are } \\
\text { irreversible }\end{array}$ & $\begin{array}{l}\text { The alien taxon is } \\
\text { toxic/allergenic by } \\
\text { ingestion, } \\
\text { inhalation, or } \\
\text { contact to wildlife or } \\
\text { allelopathic to } \\
\text { plants, resulting in } \\
\text { local or population } \\
\text { extinction of at least } \\
\text { one native species } \\
\text { (i.e., species vanish } \\
\text { from communities at } \\
\text { sites where they } \\
\text { occurred before the } \\
\text { alien arrived), } \\
\text { leading to changes } \\
\text { in community } \\
\text { composition, but } \\
\text { changes are } \\
\text { reversible when the } \\
\text { alien taxon is } \\
\text { removed }\end{array}$ & $\begin{array}{l}\text { The alien taxon is } \\
\text { toxic/allergenic by } \\
\text { ingestion, } \\
\text { inhalation, or } \\
\text { contact to wildlife or } \\
\text { allelopathic to } \\
\text { plants, resulting in a } \\
\text { decline of } \\
\text { population size of at } \\
\text { least one native } \\
\text { species, but no } \\
\text { changes in } \\
\text { community } \\
\text { composition (native } \\
\text { species richness) }\end{array}$ & $\begin{array}{l}\text { The alien taxon is } \\
\text { toxic/allergenic by } \\
\text { ingestion, inhalation, } \\
\text { or contact to wildlife } \\
\text { or allelopathic to } \\
\text { plants, affects fitness } \\
\text { (e.g., growth, } \\
\text { reproduction, } \\
\text { defence, } \\
\text { immunocompetence) } \\
\text { of native individuals } \\
\text { without decline of } \\
\text { their populations }\end{array}$ & $\begin{array}{l}\text { The alien taxon is } \\
\text { not } \\
\text { toxic/allergenic/ } \\
\text { allelopathic, or if it } \\
\text { is, the level is very } \\
\text { low, reduction of } \\
\text { fitness of native } \\
\text { individuals is not } \\
\text { detectable }\end{array}$ \\
\hline
\end{tabular}




\section{IMP1g Bio-fouling}

The accumulation of individuals of the Taxon on wetted surfaces leads to deleterious impact on native species somewhere in its global alien range.

Classify the Taxon in an impact level according to the descriptions below. If no data is available, the Response is Data Deficient (DD).

\begin{tabular}{|c|c|c|c|c|}
\hline Massive (MV) & Major (MR) & Moderate (MO) & Minor (MN) & $\begin{array}{l}\text { Minimal Concern } \\
\text { (MC) }\end{array}$ \\
\hline $\begin{array}{l}\text { Bio-fouling resulting } \\
\text { in replacement or } \\
\text { local extinction of } \\
\text { one or several } \\
\text { native species (i.e., } \\
\text { species vanish from } \\
\text { communities at } \\
\text { sites where they } \\
\text { occurred before the } \\
\text { alien arrived); } \\
\text { changes in } \\
\text { community } \\
\text { composition are } \\
\text { irreversible }\end{array}$ & $\begin{array}{l}\text { Bio-fouling resulting } \\
\text { in local or } \\
\text { population } \\
\text { extinction of at least } \\
\text { one native species, } \\
\text { leading to changes } \\
\text { in community } \\
\text { composition, but } \\
\text { changes are } \\
\text { reversible when the } \\
\text { alien taxon is } \\
\text { removed }\end{array}$ & $\begin{array}{l}\text { Bio-fouling resulting } \\
\text { in a decline of } \\
\text { population size of at } \\
\text { least one native } \\
\text { species, but no } \\
\text { changes in } \\
\text { community } \\
\text { composition }\end{array}$ & $\begin{array}{l}\text { Bio-fouling affects } \\
\text { fitness (e.g., growth, } \\
\text { reproduction, } \\
\text { defence, } \\
\text { immunocompetence) } \\
\text { of native individuals } \\
\text { without decline of } \\
\text { their populations }\end{array}$ & $\begin{array}{l}\text { Negligible level of } \\
\text { bio-fouling on } \\
\text { native species; } \\
\text { reduction of fitness } \\
\text { of native } \\
\text { individuals is not } \\
\text { detectable }\end{array}$ \\
\hline
\end{tabular}

\section{IMP1h Grazing/herbivory/browsing}

Grazing, herbivory or browsing by the Taxon leads to deleterious impact on native plant species somewhere in its global alien range.

Classify the Taxon in an impact level according to the descriptions below. If no data is available, the Response is Data Deficient (DD).

\begin{tabular}{|c|c|c|c|c|}
\hline Massive (MV) & Major (MR) & Moderate (MO) & Minor (MN) & $\begin{array}{l}\text { Minimal Concern } \\
(\mathrm{MC})\end{array}$ \\
\hline $\begin{array}{l}\text { Herbivory resulting } \\
\text { in replacement or } \\
\text { local extinction of } \\
\text { one or several } \\
\text { native plant species } \\
\text { (i.e., species vanish } \\
\text { from communities at } \\
\text { sites where they } \\
\text { occurred before the } \\
\text { alien arrived); } \\
\text { changes in } \\
\text { community } \\
\text { composition are } \\
\text { irreversible }\end{array}$ & $\begin{array}{l}\text { Herbivory resulting } \\
\text { in local or } \\
\text { population } \\
\text { extinction of at least } \\
\text { one native plant } \\
\text { species, leading to } \\
\text { changes in } \\
\text { community } \\
\text { composition, but } \\
\text { changes are } \\
\text { reversible when the } \\
\text { alien taxon is } \\
\text { removed }\end{array}$ & $\begin{array}{l}\text { Herbivory resulting } \\
\text { in a decline of } \\
\text { population size of at } \\
\text { least one native } \\
\text { species, but no } \\
\text { changes in } \\
\text { community } \\
\text { composition }\end{array}$ & $\begin{array}{l}\text { Herbivory affects } \\
\text { fitness (e.g., growth, } \\
\text { reproduction, } \\
\text { defence, } \\
\text { immunocompetence } \\
\text { ) of individual native } \\
\text { plants without } \\
\text { decline of their } \\
\text { populations }\end{array}$ & $\begin{array}{l}\text { Negligible level of } \\
\text { herbivory on native } \\
\text { plant species, } \\
\text { reduction of fitness } \\
\text { on native plants is } \\
\text { not detectable }\end{array}$ \\
\hline
\end{tabular}




\section{IMP1i Chemical, physical or structural impact on ecosystem}

The Taxon causes changes to either: the chemical, physical, and/or structural biotope characteristics of the native environment; nutrient and/or water cycling; disturbance regimes; or natural succession, leading to deleterious impact on native species somewhere in the Taxon's global alien range.

Classify the Taxon in an impact level according to the descriptions below. If no data is available, the Response is Data Deficient (DD).

\begin{tabular}{|c|c|c|c|c|}
\hline Massive (MV) & Major (MR) & Moderate (MO) & Minor (MN) & $\begin{array}{l}\text { Minimal Concern } \\
\text { (MC) }\end{array}$ \\
\hline $\begin{array}{l}\text { Many changes in } \\
\text { chemical, physical, } \\
\text { and/or structural } \\
\text { biotope } \\
\text { characteristics; or } \\
\text { changes in nutrient } \\
\text { and water cycling; } \\
\text { or disturbance } \\
\text { regimes; or } \\
\text { changes in natural } \\
\text { succession, } \\
\text { resulting in } \\
\text { replacement or local } \\
\text { extinction of native } \\
\text { species (i.e., } \\
\text { species vanish from } \\
\text { communities at } \\
\text { sites where they } \\
\text { occurred before the } \\
\text { alien arrived); } \\
\text { changes (abiotic } \\
\text { and biotic) are } \\
\text { irreversible }\end{array}$ & $\begin{array}{l}\text { Changes in } \\
\text { chemical, physical, } \\
\text { and/or structural } \\
\text { biotope } \\
\text { characteristics; or } \\
\text { changes in nutrient } \\
\text { cycling; or } \\
\text { disturbance } \\
\text { regimes; or } \\
\text { changes in natural } \\
\text { succession, } \\
\text { resulting in local } \\
\text { extinction of at least } \\
\text { one native species, } \\
\text { leading to changes } \\
\text { in community } \\
\text { composition, but } \\
\text { changes are } \\
\text { reversible when the } \\
\text { alien taxon is } \\
\text { removed }\end{array}$ & $\begin{array}{l}\text { Changes in } \\
\text { chemical, physical, } \\
\text { and/or structural } \\
\text { biotope } \\
\text { characteristics; or } \\
\text { changes in nutrient } \\
\text { cycling; or } \\
\text { disturbance } \\
\text { regimes; or } \\
\text { changes in natural } \\
\text { succession, } \\
\text { resulting in a } \\
\text { decline of } \\
\text { population size of at } \\
\text { least one native } \\
\text { species, but no } \\
\text { changes in } \\
\text { community } \\
\text { composition }\end{array}$ & $\begin{array}{l}\text { Changes in } \\
\text { chemical, physical, } \\
\text { and/or structural } \\
\text { biotope } \\
\text { characteristics; or } \\
\text { changes in nutrient } \\
\text { cycling; or } \\
\text { disturbance } \\
\text { regimes; or changes } \\
\text { in natural } \\
\text { succession } \\
\text { detectable, affecting } \\
\text { fitness (e.g., growth, } \\
\text { reproduction, } \\
\text { defence, } \\
\text { immunocompetence } \\
\text { ) of native } \\
\text { individuals without } \\
\text { decline of their } \\
\text { populations }\end{array}$ & $\begin{array}{l}\text { No changes in } \\
\text { chemical, physical, } \\
\text { and/or structural } \\
\text { biotope } \\
\text { characteristics; or } \\
\text { changes in nutrient } \\
\text { cycling; or } \\
\text { disturbance } \\
\text { regimes; or } \\
\text { changes in natural } \\
\text { succession } \\
\text { detectable, or } \\
\text { changes are small } \\
\text { with no reduction of } \\
\text { fitness of native } \\
\text { individuals } \\
\text { detectable }\end{array}$ \\
\hline
\end{tabular}




\section{IMP1k Interaction with other alien species}

The Taxon interacts with other alien taxa, (e.g., through pollination, seed dispersal, habitat modification), facilitating deleterious impact on native species somewhere in its global alien range. These interactions may be included under other impact mechanisms (e.g., predation, apparent competition) but would not have resulted in the particular level of impact without an interaction with other alien species.

Classify the Taxon in an impact level according to the descriptions below. If no data is available, the Response is Data Deficient (DD).

\begin{tabular}{|c|c|c|c|c|}
\hline Massive (MV) & Major (MR) & Moderate (MO) & Minor (MN) & $\begin{array}{l}\text { Minimal Concern } \\
\text { (MC) }\end{array}$ \\
\hline $\begin{array}{l}\text { Interaction of an } \\
\text { alien taxon with } \\
\text { other aliens (e.g., } \\
\text { pollination, seed } \\
\text { dispersal, habitat } \\
\text { modification) } \\
\text { facilitates } \\
\text { replacement or local } \\
\text { extinction of one or } \\
\text { several native } \\
\text { species (i.e., } \\
\text { species vanish from } \\
\text { communities at } \\
\text { sites where they } \\
\text { occurred before the } \\
\text { alien arrived), and } \\
\text { produces } \\
\text { irreversible changes } \\
\text { in community } \\
\text { composition that } \\
\text { would not have } \\
\text { occurred in the } \\
\text { absence of the } \\
\text { species. These } \\
\text { interactions may be } \\
\text { included under } \\
\text { other impact } \\
\text { categories (e.g., } \\
\text { predation, apparent } \\
\text { competition) but } \\
\text { would not have } \\
\text { resulted in the } \\
\text { particular level of } \\
\text { impact without an } \\
\text { interaction with } \\
\text { other alien taxa. }\end{array}$ & $\begin{array}{l}\text { Interaction of an } \\
\text { alien taxon with } \\
\text { other aliens (e.g., } \\
\text { pollination, seed } \\
\text { dispersal, habitat } \\
\text { modification) } \\
\text { facilitates local or } \\
\text { population } \\
\text { extinction of at least } \\
\text { one native species, } \\
\text { and produces } \\
\text { changes in } \\
\text { community } \\
\text { composition that are } \\
\text { reversible but would } \\
\text { not have occurred } \\
\text { in the absence of } \\
\text { the species. These } \\
\text { interactions may be } \\
\text { included under } \\
\text { other impact } \\
\text { categories (e.g., } \\
\text { predation, apparent } \\
\text { competition) but } \\
\text { would not have } \\
\text { resulted in the } \\
\text { particular level of } \\
\text { impact without an } \\
\text { interaction with } \\
\text { other alien taxa. }\end{array}$ & $\begin{array}{l}\text { Interaction of an } \\
\text { alien taxon with } \\
\text { other aliens (e.g., } \\
\text { pollination, seed } \\
\text { dispersal, habitat } \\
\text { modification) } \\
\text { facilitates a decline } \\
\text { of population size of } \\
\text { at least one native } \\
\text { species, but no } \\
\text { changes in } \\
\text { community } \\
\text { composition; } \\
\text { changes would not } \\
\text { have occurred in } \\
\text { the absence of the } \\
\text { species. These } \\
\text { interactions may be } \\
\text { included under } \\
\text { other impact } \\
\text { categories (e.g., } \\
\text { predation, apparent } \\
\text { competition) but } \\
\text { would not have } \\
\text { resulted in the } \\
\text { particular level of } \\
\text { impact without an } \\
\text { interaction with } \\
\text { other alien taxa. }\end{array}$ & $\begin{array}{l}\text { Interaction of an } \\
\text { alien taxon with } \\
\text { other aliens (e.g., } \\
\text { pollination, seed } \\
\text { dispersal) affects } \\
\text { fitness (e.g., growth, } \\
\text { reproduction, } \\
\text { defence, } \\
\text { immunocompetence } \\
\text { ) of native species' } \\
\text { individuals without } \\
\text { decline of their } \\
\text { populations; } \\
\text { changes would not } \\
\text { have occurred in the } \\
\text { absence of the } \\
\text { species. These } \\
\text { interactions may be } \\
\text { included under other } \\
\text { impact categories } \\
\text { (e.g., predation, } \\
\text { apparent } \\
\text { competition) but } \\
\text { would not have } \\
\text { resulted in the } \\
\text { particular level of } \\
\text { impact without an } \\
\text { interaction with } \\
\text { other alien taxa. }\end{array}$ & $\begin{array}{l}\text { Interaction of an } \\
\text { alien taxon with } \\
\text { other aliens (e.g., } \\
\text { pollination, seed } \\
\text { dispersal) but with } \\
\text { minimal effects on } \\
\text { native species; } \\
\text { reduction of fitness } \\
\text { of native individuals } \\
\text { is not detectable }\end{array}$ \\
\hline
\end{tabular}




\section{IMP2 Socio-economic impact}

Assess the socio-economic impact of the Taxon in its global alien range (i.e. everywhere it has been introduced outside of its native range). Perform a generic impact scoring on the Taxon as described in IMP2a) to IMP2g) below. This concerns impacts on the following sectors:

(a) agriculture

(b) animal production

(c) mariculture/aquaculture

(d) forestry

(e) infrastructure

(f) human health

(g) human social life

Fill in the Answer sheet for each of the sectors (IMP2a-IMP2g), and use Figure 3 to calculate the main socio-economic impact score. Report on the maximum impact found in any of the sectors and any alien range in the Response to IMP2, and the main sector affected in the Rationale, but provide information on all the sectors and impact scores in IMP2a)-2g), including detailed information on the references used for the assessments.

If no data on impact are available for the Taxon in any part of its alien range globally on any of the sectors described below, mark the Taxon as Data Deficient (DD) here and additionally fill in IMP4.

\section{IMP2a Impacts on agricultural production}

This concerns impacts through damage to crops or plantations, but also to horticultural and stored products. Impacts include competition with weeds, direct feeding damage (from feeding traces which reduce marketability to complete production loss) but also reduced accessibility, usability or marketability through contamination. Impacts include the need for applying pesticides which involve additional costs, also by reducing market quality. Impacts usually lead to an economic loss.

Classify the Taxon in an impact level according to the descriptions below. If no data is available, the Response is Data Deficient (DD).

\begin{tabular}{lllll}
\hline Massive (MV) & Major (MR) & Moderate (MO) & Minor (MN) & $\begin{array}{l}\text { Minimal } \\
\text { (MC) }\end{array}$ \\
\hline $\begin{array}{llll}\text { Major impacts with } \\
\text { complete }\end{array}$ & $\begin{array}{l}\text { Major impacts with } \\
\text { high damage, often }\end{array}$ & $\begin{array}{l}\text { Medium impacts, } \\
\text { large-scale or }\end{array}$ & $\begin{array}{l}\text { Minor impacts, in } \\
\text { the range of native }\end{array}$ & $\begin{array}{l}\text { Minor impacts, in } \\
\text { the range of native }\end{array}$ \\
$\begin{array}{ll}\text { destruction and } \\
\text { economic loss. }\end{array}$ & occurring or with & frequently, pesticide & species, but more & species, only \\
& high probability, & application & wide-spread, minor & locally, negligible \\
& major economic & necessary, medium & economic loss. & economic loss. \\
& loss. & economic loss. & & \\
\hline
\end{tabular}

\section{IMP2b Impacts on animal production}

Impacts through competition with livestock, transmission of diseases or parasites to livestock and predation of livestock. Intoxication of livestock through changes in food palatability, secondary plant compounds or toxins, weakening or injuring livestock, e.g. by stinging or biting. Also impacts on livestock environment such as pollution by droppings on farmland which domestic stock are then reluctant to graze. Hybridization with livestock. Impacts include the need for applying pesticides which involve additional costs, also by reducing market quality. Impacts usually lead to an economic loss. Classify the Taxon in an impact level according to the descriptions below. If no data is available, the Response is Data Deficient (DD).

\begin{tabular}{|c|c|c|c|c|}
\hline Massive (MV) & Major (MR) & Moderate (MO) & Minor (MN) & $\begin{array}{l}\text { Minimal Concern } \\
(\mathrm{MC})\end{array}$ \\
\hline $\begin{array}{l}\text { Major impacts with } \\
\text { complete } \\
\text { destruction and } \\
\text { economic loss. }\end{array}$ & $\begin{array}{l}\text { Major impacts with } \\
\text { high damage, often } \\
\text { occurring or with } \\
\text { high probability, } \\
\text { major economic } \\
\text { loss. }\end{array}$ & $\begin{array}{l}\text { Medium impacts, } \\
\text { large-scale or } \\
\text { frequently, pesticide } \\
\text { application } \\
\text { necessary, medium } \\
\text { economic loss. }\end{array}$ & $\begin{array}{l}\text { Minor impacts, in } \\
\text { the range of native } \\
\text { species, but more } \\
\text { wide-spread, minor } \\
\text { economic loss. }\end{array}$ & $\begin{array}{l}\text { Minor impacts, in } \\
\text { the range of native } \\
\text { species, only } \\
\text { locally, negligible } \\
\text { economic loss. }\end{array}$ \\
\hline
\end{tabular}




\section{IMP2c Impacts on mariculture/aquaculture}

Impacts through competition with taxa in mariculture/aquaculture, transmission of diseases or parasites to taxa in mariculture/aquaculture and predation of cultured taxa. Also impacts on culture environment such as pollution by droppings in water. Hybridization with cultured taxa. Impacts include reduction in market quality. Impacts usually lead to an economic loss.

Classify the Taxon in an impact level according to the descriptions below. If no data is available, the Response is Data Deficient (DD).

\begin{tabular}{lllll}
\hline Massive (MV) & Major (MR) & Moderate (MO) & Minor (MN) & $\begin{array}{l}\text { Minimal } \\
\text { (MC) }\end{array}$ \\
\hline $\begin{array}{llll}\text { Major impacts with } \\
\text { complete }\end{array}$ & $\begin{array}{l}\text { Major impacts with } \\
\text { high damage, often }\end{array}$ & $\begin{array}{l}\text { Medium impacts, } \\
\text { large-scale or }\end{array}$ & $\begin{array}{l}\text { Minor impacts, in } \\
\text { the range of native }\end{array}$ & $\begin{array}{l}\text { Minor impacts, in } \\
\text { the range of native }\end{array}$ \\
economic loss. & occurring or with & frequently, pesticide & species, but more & species, only \\
& high probability, & application & wide-spread, minor & locally, negligible \\
& major economic & necessary, medium & economic loss. & economic loss. \\
& loss. & economic loss. & & \\
\hline
\end{tabular}

\section{IMP2d Impacts on forestry production}

Impacts on forests or forest products through plant competition, parasitism, diseases, herbivory, effects on tree or forest growth and on seed dispersal. Impacts may affect forest regeneration through browsing on young trees, bark gnawing or stripping and antler rubbing. Damage includes felling trees, defoliating them for nesting material or causing floods. Impacts include the need for applying pesticides which involve additional costs, also by reducing market quality. Impacts usually lead to an economic loss.

Classify the Taxon in an impact level according to the descriptions below. If no data is available, the Response is Data Deficient (DD).

\begin{tabular}{|c|c|c|c|c|}
\hline Massive (MV) & Major (MR) & Moderate (MO) & Minor (MN) & $\begin{array}{l}\text { Minimal Concern } \\
\text { (MC) }\end{array}$ \\
\hline $\begin{array}{l}\text { Major impacts with } \\
\text { complete } \\
\text { destruction and } \\
\text { economic loss. }\end{array}$ & $\begin{array}{l}\text { Major impacts with } \\
\text { high damage, often } \\
\text { occurring or with } \\
\text { high probability, } \\
\text { major economic } \\
\text { loss. }\end{array}$ & $\begin{array}{l}\text { Medium impacts, } \\
\text { large-scale or } \\
\text { frequently, pesticide } \\
\text { application } \\
\text { necessary, medium } \\
\text { economic loss. }\end{array}$ & $\begin{array}{l}\text { Minor impacts, in } \\
\text { the range of native } \\
\text { species, but more } \\
\text { wide-spread, minor } \\
\text { economic loss. }\end{array}$ & $\begin{array}{l}\text { Minor impacts, in } \\
\text { the range of native } \\
\text { species, only } \\
\text { locally, negligible } \\
\text { economic loss. }\end{array}$ \\
\hline
\end{tabular}

\section{IMP2e Impacts on human infrastructure and administration}

Impacts include damage to human infrastructure, such as roads and other traffic infrastructure, buildings, damps, docks, fences, electricity cables (e.g. by gnawing or nesting on them) or through pollution (e.g. by droppings). Impacts through root growth, plant cover in open water bodies or digging activities on watersides, roadside embankments and buildings may affect flood defence systems, traffic infrastructure or stability of buildings. Impacts may affect human safety and cause traffic accidents. Impacts include the need for applying pesticides, their development costs and further registration or administration costs, as well as costs for research and control. Impacts usually lead to an economic loss.

Classify the Taxon in an impact level according to the descriptions below. If no data is available, the Response is Data Deficient (DD).

\begin{tabular}{|c|c|c|c|c|}
\hline Massive (MV) & Major (MR) & Moderate (MO) & Minor (MN) & $\begin{array}{l}\text { Minimal Concern } \\
(\mathrm{MC})\end{array}$ \\
\hline $\begin{array}{l}\text { Major impacts with } \\
\text { complete } \\
\text { destruction and } \\
\text { economic loss. }\end{array}$ & $\begin{array}{l}\text { Major impacts with } \\
\text { high damage, often } \\
\text { occurring or with } \\
\text { high probability, } \\
\text { major economic } \\
\text { loss. }\end{array}$ & $\begin{array}{l}\text { Medium impacts, } \\
\text { large-scale or } \\
\text { frequently, pesticide } \\
\text { application } \\
\text { necessary, medium } \\
\text { economic loss. }\end{array}$ & $\begin{array}{l}\text { Minor impacts, in } \\
\text { the range of native } \\
\text { species, but more } \\
\text { wide-spread, minor } \\
\text { economic loss. }\end{array}$ & $\begin{array}{l}\text { Minor impacts, in } \\
\text { the range of native } \\
\text { species, only } \\
\text { locally, negligible } \\
\text { economic loss. }\end{array}$ \\
\hline
\end{tabular}




\section{IMP2f Impacts on human health}

Injuries (e.g. bites, stings, scratches, rashes), transmission of diseases and parasites to humans, bioaccumulation of noxious substances, health hazard due to contamination with pathogens or parasites (e.g. of water, soil, food, or by faeces or droppings), as well as secondary plant compounds, toxins or allergen substances such as pollen. Impacts include the need for applying pesticides which due to their low selectivity and/or residues may have side-effects on humans. Via health costs, impacts usually lead to economic costs.

Classify the Taxon in an impact level according to the descriptions below. If no data is available, the Response is Data Deficient (DD).

\begin{tabular}{|c|c|c|c|c|}
\hline Massive (MV) & Major (MR) & Moderate (MO) & Minor (MN) & $\begin{array}{l}\text { Minimal Concern } \\
(\mathrm{MC})\end{array}$ \\
\hline $\begin{array}{l}\text { Major impacts, fatal } \\
\text { issues, high } \\
\text { economic costs. }\end{array}$ & $\begin{array}{l}\text { Major impacts with } \\
\text { high damage, often } \\
\text { occurring or with } \\
\text { high probability, but } \\
\text { rarely fatal, major } \\
\text { economic costs. }\end{array}$ & $\begin{array}{l}\text { Medium impacts, } \\
\text { large-scale or } \\
\text { frequently, pesticide } \\
\text { application } \\
\text { necessary, medium } \\
\text { economic loss. }\end{array}$ & $\begin{array}{l}\text { Minor impacts, in } \\
\text { the range of native } \\
\text { species, but more } \\
\text { wide-spread, minor } \\
\text { economic loss. }\end{array}$ & $\begin{array}{l}\text { Minor impacts, in } \\
\text { the range of native } \\
\text { species, only } \\
\text { locally, negligible } \\
\text { economic loss. }\end{array}$ \\
\hline
\end{tabular}

\section{IMP2g Impacts on human social life}

Noise disturbance, pollution of recreational areas (water bodies, rural parks, golf courses or city parks), including fouling, eutrophication, damage by trampling and overgrazing, restrictions in accessibility (e.g. by thorns, other injuring structures, successional processes, or recent pesticide application) to habitats or landscapes of recreational value. Restrictions or loss of recreational activities.

Classify the Taxon in an impact level according to the descriptions below. If no data is available, the Response is Data Deficient (DD).

\begin{tabular}{|c|c|c|c|c|}
\hline Massive (MV) & Major (MR) & Moderate (MO) & Minor (MN) & $\begin{array}{l}\text { Minimal Concern } \\
(\mathrm{MC})\end{array}$ \\
\hline $\begin{array}{l}\text { Major impacts with } \\
\text { complete } \\
\text { destruction and loss } \\
\text { of recreational } \\
\text { value, major } \\
\text { economic loss. }\end{array}$ & $\begin{array}{l}\text { Major impacts with } \\
\text { high damage, often } \\
\text { occurring or with } \\
\text { high probability, } \\
\text { recreational value of } \\
\text { a location strongly } \\
\text { affected, major } \\
\text { economic loss. }\end{array}$ & $\begin{array}{l}\text { Medium impacts, } \\
\text { large-scale or } \\
\text { frequently, pesticide } \\
\text { application } \\
\text { necessary, medium } \\
\text { economic loss. }\end{array}$ & $\begin{array}{l}\text { Minor impacts, in } \\
\text { the range of native } \\
\text { species, but more } \\
\text { wide-spread, minor } \\
\text { economic loss. }\end{array}$ & $\begin{array}{l}\text { Minor impacts, in } \\
\text { the range of native } \\
\text { species, only } \\
\text { locally, negligible } \\
\text { economic loss. }\end{array}$ \\
\hline
\end{tabular}

\section{IMP3 Closely related taxons' environmental impact}

This section is only considered if the Response is Data Deficient (DD) in IMP1.

Consider here data of congeners or other closely related taxa with similar life history traits and their environmental impacts in their global alien range. In detail, perform a classification of impacts as described in IMP1a-IMP1k for closely related and similar taxa. Note which taxa was/were considered in the Rationale, and report on the details of the different impact mechanisms on the Answer sheet. In the Response to IMP3, note the maximum impact found in any mechanism.

\section{IMP4 Closely related taxons' socio-economic impact}

This section is only considered if the Response is Data Deficient (DD) in IMP2.

Consider here data of congeners or other closely related taxa with similar life history traits and their socio-economic impacts in their global alien range. More specifically, perform a classification of impacts as described in IMP2a-IMP2f for closely related and similar taxa. Note which taxa was/were considered in the Rationale, and report on the details of the different sectors on the Answer sheet. In the Response to IMP4, note the maximum impact found on any sector. 


\section{IMP5 Potential impact}

This is filled in for all taxa regardless of whether information on the other impact questions (IMP1-4) is available. Ideally, experiments should be performed on impacts of taxa for which no information is available regarding consequences of invasions, but this is hardly feasible for all taxa. Therefore, if no data is available on impacts in any introduced region of the Taxon and any closely related taxon, use data from the native range of the Taxon and/or estimate the magnitude of impact possible for the Taxon in the Area based on its life history traits and trait based models for other taxa.

In detail, estimate the potential of the Taxon to cause any impact in the magnitudes as described under IMP1 and IMP2 in the Area, including impacts for which no evidence has been recorded yet. Assume the Taxon is established and abundant in the Area, and consider the highest impact possible under any of the mechanisms and to any sector. Here we consider the life history traits of the Taxon which could lead to impact, including undesirable traits, as well as the recipient systems, meaning the recipient habitat and community. In some cases, impacts caused in the native range can be useful indicators of impact, for example impacts on agriculture.

Undesirable traits include (but do not exclusively consist of): produces spines, thorns or burrs, allelopathic, parasitic, unpalatable to grazing animals, toxic to animals, host for recognised pests and pathogens, causes allergies or is otherwise toxic to humans, creates a fire hazard in natural ecosystems, grows on infertile soils, shade tolerant plant at some stage of its life cycle. Also consider here feeding habits, novelty aspects, functional traits, and studies performed on other groups and taxa considering trait-impact relationships.

\begin{tabular}{|c|c|c|c|c|c|}
\hline Impact levels & Massive (MV) & Major (MR) & Moderate (MO) & Minor (MN) & $\begin{array}{l}\text { Minimal Concern } \\
\text { (MC) }\end{array}$ \\
\hline $\begin{array}{l}\text { Environmental } \\
\text { impact (IMP1 } \\
\text { \& IMP3) }\end{array}$ & $\begin{array}{l}\text { Causes at least } \\
\text { local extinction of } \\
\text { native species, } \\
\text { and irreversible } \\
\text { changes in } \\
\text { community } \\
\text { composition; } \\
\text { even if the alien } \\
\text { taxon is removed } \\
\text { the system does } \\
\text { not recover its } \\
\text { original state }\end{array}$ & $\begin{array}{l}\text { Causes } \\
\text { changes in } \\
\text { community } \\
\text { composition, } \\
\text { which are } \\
\text { reversible if } \\
\text { the alien taxon } \\
\text { is removed }\end{array}$ & $\begin{array}{l}\text { Causes } \\
\text { population } \\
\text { declines in } \\
\text { native species, } \\
\text { but no changes } \\
\text { in community } \\
\text { composition }\end{array}$ & $\begin{array}{l}\text { Causes } \\
\text { reductions in } \\
\text { individual } \\
\text { fitness, but no } \\
\text { declines in } \\
\text { native } \\
\text { population } \\
\text { sizes. }\end{array}$ & $\begin{array}{l}\text { No effect on } \\
\text { fitness of } \\
\text { individuals of } \\
\text { native species }\end{array}$ \\
\hline $\begin{array}{l}\text { Socio- } \\
\text { economic } \\
\text { impact (IMP2 } \\
\text { \& IMP4) }\end{array}$ & $\begin{array}{l}\text { Major impacts } \\
\text { with complete } \\
\text { destruction and } \\
\text { economic loss. }\end{array}$ & $\begin{array}{l}\text { Major impacts } \\
\text { with high } \\
\text { damage, often } \\
\text { occurring or } \\
\text { with high } \\
\text { probability, } \\
\text { major } \\
\text { economic loss. }\end{array}$ & $\begin{array}{l}\text { Medium } \\
\text { impacts, large- } \\
\text { scale or } \\
\text { frequently, } \\
\text { pesticide } \\
\text { application } \\
\text { necessary, } \\
\text { medium } \\
\text { economic loss. }\end{array}$ & $\begin{array}{l}\text { Minor impacts, } \\
\text { in the range of } \\
\text { native species, } \\
\text { but more wide- } \\
\text { spread, minor } \\
\text { economic loss. }\end{array}$ & $\begin{array}{l}\text { Minor impacts, } \\
\text { similar to native } \\
\text { species, only } \\
\text { locally, negligible } \\
\text { economic loss. }\end{array}$ \\
\hline $\begin{array}{l}\text { Potential } \\
\text { impact } \\
\text { (IMP5) }\end{array}$ & $\begin{array}{l}\text { The Taxon is a } \\
\text { transformer in its } \\
\text { native range, has } \\
\text { ecosystem } \\
\text { engineering } \\
\text { properties, or } \\
\text { possesses other } \\
\text { traits which } \\
\text { suggest } \\
\text { irreversible } \\
\text { impacts on the } \\
\text { community } \\
\text { composition in } \\
\text { the Area to occur. } \\
\text { The Taxon is a } \\
\text { pest of } \\
\text { agricultural } \\
\text { production in the } \\
\text { native range } \\
\text { and/or has the } \\
\text { potential to cause } \\
\text { high losses. }\end{array}$ & $\begin{array}{l}\text { The Taxon } \\
\text { has traits } \\
\text { which suggest } \\
\text { major impacts } \\
\text { on native } \\
\text { communities } \\
\text { in the Area, } \\
\text { but these } \\
\text { impacts are } \\
\text { likely to be } \\
\text { reversible. The } \\
\text { Taxon has } \\
\text { traits which } \\
\text { can lead to } \\
\text { high losses to } \\
\text { economy. }\end{array}$ & $\begin{array}{l}\text { The Taxon } \\
\text { possesses } \\
\text { several } \\
\text { undesirable } \\
\text { traits. Due to the } \\
\text { traits of the } \\
\text { Taxon and/or its } \\
\text { behavior, it is } \\
\text { expected to } \\
\text { reduce } \\
\text { population sizes } \\
\text { of at least one } \\
\text { native species. } \\
\text { Economic loss is } \\
\text { expected to be } \\
\text { medium. }\end{array}$ & $\begin{array}{l}\text { The Taxon } \\
\text { does not } \\
\text { possess any } \\
\text { traits which } \\
\text { could lead to } \\
\text { effects on } \\
\text { native species } \\
\text { population } \\
\text { sizes, but } \\
\text { reduction in } \\
\text { native } \\
\text { individuals' } \\
\text { fitness is } \\
\text { expected. } \\
\text { Minor } \\
\text { economic loss } \\
\text { is possibly } \\
\text { widespread. }\end{array}$ & $\begin{array}{l}\text { Due to the traits of } \\
\text { the Taxon no } \\
\text { effect on native } \\
\text { individuals' fitness } \\
\text { is expected. No } \\
\text { socio-economic } \\
\text { loss is expected. } \\
\text { The Taxon does } \\
\text { not possess any } \\
\text { undesirable traits. }\end{array}$ \\
\hline
\end{tabular}




\section{Risk assessment}

The risk posed by an alien Taxon is the likelihood the Taxon will become an invader and the consequences in terms of impact resulting from the introduction of the Taxon. The Likelihood for the risk assessment is derived from LIK1-LIK6 as described in Figure 2 and Table 2. Consequences are derived from IMP1-IMP5, as summarised in Figure 3. Table 3 summarises how risk scores are derived from Consequences and Likelihood.

If the risk of the Taxon to become a harmful invader is medium or high (according to Table 3), the management options section needs to be assessed. If the risk is low, the Taxon does not need to be listed but under certain circumstances could be monitored in the region it occurs. The Risk assessment therefore provides the evidence base for or against the listing of a Taxon under the NEMBA Regulations, whereas the Risk management section helps to decide which listing status could be considered (Figure 4).

\section{4) Management}

Once a risk has been identified and assessed as of concern (i.e. medium or high risk, Table 3), the next step is to consider what can be done to manage the risk. This will ultimately often require a detailed evaluation of management options, the development of costed management plans, and a process of prioritisation of different potential interventions. As with other aspects of the framework the decision of the approach to apply in practice will ultimately also be a political one that is constrained by the available resources. Therefore, the aim of this section is to provide some guidance as to which management goals should be investigated and what information is required in order to proceed further. Notably, this section does not go into detail and other guidelines and processes are required for more sophisticated recommendations to be developed (e.g. guidelines are needed to determine permit conditions that could be implemented in practice to reduce the invasion risk to an acceptable level; and guidelines are needed to evaluate eradication feasibility).

Generally, whether or not to list a Taxon under a legal framework can be derived from the risk assessment as described under section 2, 3, and in Tables 2-4. These are evidence based assessments incorporating scientific knowledge about the Taxon, and transferring this knowledge to the Area and situation at hand. Here, input from taxon specialists, ecologists, biologists and invasion scientists can be most useful. International agreements need to be considered for the listing of taxa under such regulations as such listing is generally linked with trade restrictions.

The distinction between whether or not to regulate and list a Taxon relies on scientific evidence. However, decisions regarding permitting or allowance of certain activities involving the Taxon also rely on social perceptions and benefits. Therefore, this information needs to be collected and included in the analysis, but no clear cutoff levels for decisions in terms of listing categories are given. It is the responsibility 
of the decision makers to take the information in this assessment and based on the best information available, make the final decision on listing.

A decision on the listing status, i.e., whether a taxon should be listed as prohibited, Category 1a, 1b, 2 or 3 as outlined in the NEM:BA A\&IS Regulations, is not only based on scientific evidence, but often relies on the value of the Taxon, besides some inherent features which make it more or less easy to control. Therefore, risk management considerations describing whether and how risks can be managed apply, including benefits (Table 4 and MAN questions).

Based on this information, we consider seven broad recommendations. These differ based on whether the Taxon is already present or not, whether prevention or eradication are feasible goals, and whether the Taxon has benefits to the Area such that it might be a conflict species that could be allowed under permit in certain conditions (Figure 4).

\section{MAN1 What is the feasibility to stop future immigration?}

Assess here if future immigration of the Taxon into the Area can be prevented. If the Taxon is already present as an alien in the Area (see BAC10), this is needed to determine whether eradication is a feasible goal. If the Taxon is not yet in the Area this determines whether prevention is a feasible goal. Based on the pathways identified in BAC14 and the answers provided in LIK1 and LIK2, estimate the feasibility to stop propagules from entering the Area.

High: The Taxon is introduced into the Area intentionally with pathways which are easy to regulate and control.

Low: The Taxon is introduced into the Area unintentionally, for example as contaminant and stowaway, and/or is present in neighbouring countries and areas and is entering the Area unaided.

\section{MAN2 Benefits of the Taxon}

Taxa with significant benefits and significant costs are sometimes termed conflict species. The benefits might be in terms of either socio-economy or the environment. Crucially the benefits of an introduction are often spatially and temporally separated from the costs of an invasion. This section (MAN2a \& MAN2b) aims at assessing socio-economic and environmental benefits to highlight potential conflicts of interest. Stakeholders might need to be consulted to answer these questions (see also Supplementary Material Appendix S7). Summarise the benefits using the maximum of both, socio-economic and environmental benefits as outlines below. Keep in mind that conflicts are expected especially if socio-economic benefits are significant.

\section{MAN2a Socio-economic benefits of the Taxon}

Socio-economic benefits, if appropriate, should be described to ensure an objectivity and recognition of the services that may be provided by the Taxon. Under Rational and comments, list the benefits and the significance of each. Include here if the Taxon is used for any of the following: as pet, in horticulture, for fencing, shading, dune stabilisation, firewood, building material, hunting, fishing, human food, animal feed and fodder, fabric production, etc. Benefits are rated as of high or low significance, based on the criteria outlined below. Details of the benefits and why they are rated in the respective level need to be provided in the Rationale.

High: Significant benefits are expected if the Taxon provides a service or makes an activity possible which is not available without the Taxon, i.e., which is not provided by the native species in the Area. Also covered here are services provided by the Taxon which are essential for security, adequate livelihoods, sufficient nutritious food, access to clean air and water, and food.

Low: List benefits which can relatively easily be replaced by another (native or non-harmful alien) taxon, for example pets, trees providing firewood, game for hunting, horticultural plants, trees for shade, cacti for fencing. Depending on the size of the affected industry, conflicts are still possible 
therefore it is important to outline these benefits regardless. Also covered here are services provided by the Taxon which affect aspects of human well-being related to social, spiritual and cultural relations, for example friendship and spiritual practices.

\section{MAN2b Environmental benefits of the Taxon}

Here, benefits to the natural environment and native species in the Area are assessed. Benefits are rated as of high or low significance, based on the criteria outlined below. Details of the benefits and why they are rated in the respective level need to be provided in the Rationale.

High: High benefits are expected if the Taxon provides a crucial habitat or food source to an environment. These functions might be replaceable over time by native taxa, but it indicates that current control would be detrimental to conservation or ecosystem functioning. Significant benefits are also noted if the Taxon provides resources which are not or no longer available without the Taxon present to native species, especially to rare, endemic or threatened species.

Low: Benefits to native species and ecosystems which can relatively easily be replaced by another (native or non-harmful alien) taxon.

\section{MAN3 Ease of management}

Some invasions are notoriously difficult to control, and this influences both the decisions concerning risk management and how the risks should be communicated. Values as described in MAN3a-MAN3d are assigned for situations where the Taxon has been detected, not where it could be found, in the Area. So this is only relevant if the Taxon is present in the Area (BAC10). Provide detailed answers to MAN3a-MAN3d in the Answer sheet and use Table 4 to calculate the ease of management, i.e. the sum of the answers.

\section{Response options:}

$>5$ : Difficult. Generally difficult to manage (e.g. specialist equipment or techniques are required / multiple approaches are needed for control to be effective / management is an expensive operation over several seasons)

3-5: Medium. Some aspects make it difficult to manage

$<3$ : Easy. Management is relatively straightforward (e.g. can be achieved without substantial training or repeated control efforts)

\section{MAN3a How accessible are populations?}

Moderately accessible will include regions that pose some operational difficulty, but that might not necessarily require specialised teams (e.g. a riparian area). To be rated as difficult to access, the incursion must involve at least some sites that are very difficult to access (e.g. a ravine).

\section{Response options:}

0 for easy access

1 for moderately accessible

2 for difficult to access; or don't know

\section{MAN3b Is detectability critically time-dependent?}

The objective of this question is to distinguish taxa that are readily detectable throughout the year from those that might be detectable only for short periods (e.g. following the production of new foliage or as dispersing adults). If the Taxon is detectable relatively briefly it provide only small windows for control prior to reproductive events.

\section{Response options: \\ 0 for no \\ 2 for yes; or don't know}




\section{MAN3c Time to reproduction}

It will be more difficult to prevent reproduction of a Taxon that reproduces quickly than those that have extended juvenile periods. Default value (i.e. if unknown) is 1 .

Response options:

0 for $>3$ years

1 for $1-3$ years; or don't know

2 for $<1$ year

\section{MAN3d Propagule persistence}

Propagule persistence is often one of the most important impedance factors, since it sets the minimum duration for an eradication programme. Propagules comprise of e.g., resting stages, seeds, spores, vegetative fragments. Default value is 1.

\section{Response options:}

0 for $<1$ year

1 for $1-5$ years; or don't know

3 for $>5$ years

\section{MAN4 Has the feasibility of eradication been evaluated?}

Determining whether eradication is a feasible goal is a process in and of itself, requiring some of the information that is used elsewhere in this framework [e.g. whether it is feasible to stop future immigration (MAN1), and the overall ease of management (MAN3)], but also much more. Most of this information will only become available as control effort are piloted (see Wilson et al. 2017 for detailed guidelines for evaluating eradication feasibility and monitoring progress). A detailed evaluation of eradication feasibility will at a minimum include: explicit delimitation of populations, trial management, an assessment of current status, a risk map, a bioeconomic / decision support model showing costs and potential success of different control scenarios (e.g. Moore et al. 2011), and a proposed management strategy with time-lines and specific goals.

Given there is often a short temporal window during which eradication is feasible (and after which the Taxon has become too widespread and numerous in the Area) it is important that control efforts are not delayed until a regulatory decision has been finalised. Therefore, under this framework, a recommendation is not dependent on whether the feasibility of eradication has been evaluated or not. However, only if there has been a specific and detailed evaluation should eradication be set as the management goal in the regulations. If the pilot management achieves eradication before formal regulatory confirmation of an eradication attempt, then it will in no way limit future options (unlikely delaying eradication until it is too late).

\section{Response options:}

Yes: there has been a detailed evaluation of eradication feasibility that has been documented (e.g. in a journal article).

No: there has been no evaluation of eradication or the evaluation is not detailed

\section{5) Reporting}

Figure 4 describes how to arrive at certain recommendations for Risk management and listing from the answers provided in the Risk analysis.

A summary sheet including the conclusions from each table should be provided, with short descriptions on the Taxon itself, impacts, risks, management options and benefits. An example is given in the Supplementary Material Appendix S5, based on the Reporting template in the Answer sheet. The full risk analysis with each question answered and all references, including detailed information on assessors, reviewers, Taxon and Area, and maps should be provided. 


\section{Testing and review of framework}

This framework has been reviewed and approved by the Alien Species Risk Analysis Review Panel (ASRARP). Furthermore, it was tested on a wide variety of taxa and by representatives of various organisations, including the South African National Biodiversity Institute (SANBI), the Department of Environmental Affairs (DEA), the Centre for Invasion Biology at Stellenbosch University, and ASRARP. Comments received were subsequently addressed to improve clarity of the framework and assessment process.

All Risk analyses performed are to be reviewed by ASRARP. Furthermore, Risk analysis can be updated if more information becomes available, and they should be regularly re-assessed. Cut-off levels for low, medium and high risk respectively (Table 3) can be adapted if needed or as appropriate.

Even though the Risk analysis framework presented here is mainly intended for the use as post-border assessment to underpin the listing of alien taxa under the NEMBA Regulations, it can also be used as a pre-border assessment to analyse the risk of taxa not yet present in the country. 


\section{References}

Blackburn TM, EssI F, Evans T, Hulme PE, Jeschke JM, Kühn I, Kumschick S, Mrugała A, Marková Z, Nentwig W, Pergl J, Pyšek P, Rabitsch W, Ricciardi A, Richardson DM, Sendek A, Vilà M, Wilson JRU, Winter M, Genovesi P \& Bacher S (2014) A unified classification of alien species based on the magnitude of their environmental impacts. PLoS Biology 12(5): e1001850

Blackburn TM, Pyšek P, Bacher S, Carlton JT, Duncan RP, et al. (2011) A proposed unified framework for biological invasions. Trends Ecol Evol 26: 333-339.

Department of Environmental Affairs (2014) National Environmental Management: Biodiversty Act 2004 (Act No. 10 of 2004) Alien and Invasive Species Regulations, 2014. Government Gazette Vol. 590, No. 37885

Essl F, Nehring S, Klingenstein F, Milasowszky N, Nowack C \& Rabitsch W (2011) Review of risk assessment systems of IAS in Europe and introducing the German-Austrian Black List Information system (GABLIS). Journal for Nature Conservation 19: 339350.

Hawkins CL, Bacher S, EssI F, Hulme PE, Jeschke JM, Kühn I, Kumschick S, Nentwig W, Pergl J, Pyšek P, Rabitsch W, Richardson DM, Vilà M, Wilson JRU, Genovesi P \& Blackburn TM (2015) Framework and guidelines for implementing the proposed IUCN Environmental Impact Classification for Alien Taxa (EICAT). Diversity and Distributions 21: 1360-1363

Kumschick S, Bacher S, Marková Z, Pergl J, Pyšek P, Vaes-Petignat S, van der Veer G, Vilà M \& Nentwig W (2015) Comparing impacts of alien plants and animals using a standard scoring system. Journal of Applied Ecology 52: 552-561

Moore JL, Runge MC, Webber BL \& Wilson JRU (2011) Contain or eradicate? Optimizing the management goal for Australian acacia invasions in the face of uncertainty. Diversity and Distributions 17: 1047-1059.

Nentwig W, Bacher S, Pyšek P, Vilà M \& Kumschick S (2016) The Generic Impact Scoring System (GISS): a standardized tool to quantify the impacts of alien species. Environmental Monitoring and Assessment 188: 315

Panetta FD \& Timmins SM (2004) Evaluating the feasibility of eradication for terrestrial weed invasions. Plant Protection Quarterly 19: 5-11.

Peel MC, Finlayson BL, McMahon TA (2007) Updated world map of the Koppen-Geiger climate classification. Hydrology and Earth System Sciences 11: 1633-1644

Richardson DM and Thuiller W (2007) Home away from home - objective mapping of highrisk source areas for plant introductions. Diversity and Distributions 13: 299-312

Wilson JR, Panetta FD \& Lindgren C (2017) Detecting and responding to alien plant incursions. Cambridge University Press. 


\section{Risk Analysis Report}

(the following table is to be completed once all the other sections are completed, but will appear at the front of the report)

\begin{tabular}{|c|c|c|}
\hline $\begin{array}{l}\text { Taxon: } \\
\text { (as in BAC4) }\end{array}$ & \multicolumn{2}{|l|}{$\begin{array}{l}\text { Area: } \\
\text { (as in BAC9) }\end{array}$} \\
\hline $\begin{array}{l}\text { Compiled by: } \\
\text { (from BAC1) }\end{array}$ & \multicolumn{2}{|l|}{$\begin{array}{l}\text { Approved by: } \\
\text { (leave empty) }\end{array}$} \\
\hline Picture of Taxon & \multicolumn{2}{|c|}{ Alien distribution map (BAC8) } \\
\hline \multicolumn{2}{|c|}{$\begin{array}{l}\text { Risk Assessment summary: } \\
\text { Summarise here the answers to questions under section 2) LIK and section 3) IMP, and from } \\
\text { Table 3. Emphasise the situation in the Area, if such information is available. }\end{array}$} & $\begin{array}{l}\text { Risk score: } \\
\text { (from Table 3) }\end{array}$ \\
\hline \multicolumn{2}{|c|}{$\begin{array}{l}\text { Management options summary: } \\
\text { Report on the main findings from section 4) MAN, which includes benefits and questions on the } \\
\text { ease of control. Indicate whether an eradication feasibility study was done, or is necessary based } \\
\text { on the assessment. }\end{array}$} & $\begin{array}{l}\text { Ease of } \\
\text { management: }\end{array}$ \\
\hline \multicolumn{2}{|c|}{$\begin{array}{l}\text { Recommendations: } \\
\text { According to the decision tree as presented in Figure } 4 \text {. This should also include } \\
\text { recommendations on further studies needed, management plans, stakeholder engagement, etc. }\end{array}$} & $\begin{array}{l}\text { Listing category: } \\
\text { (as in Figure 4) }\end{array}$ \\
\hline
\end{tabular}




\section{Background}

\begin{tabular}{|c|c|c|}
\hline \multicolumn{3}{|c|}{ BAC1 Name of assessor(s) } \\
\hline \multicolumn{3}{|l|}{$\begin{array}{l}\text { Name of lead } \\
\text { assessor }\end{array}$} \\
\hline \multicolumn{3}{|l|}{$\begin{array}{l}\text { Additional } \\
\text { assessor (1) }\end{array}$} \\
\hline \multicolumn{3}{|l|}{$\begin{array}{l}\text { Additional } \\
\text { assessor (2) }\end{array}$} \\
\hline \multicolumn{3}{|c|}{ BAC2 Contact details of assessor (s) } \\
\hline \multirow[t]{3}{*}{ Lead assessor } & \multicolumn{2}{|l|}{ Organisational affiliation: } \\
\hline & \multicolumn{2}{|l|}{ email: } \\
\hline & \multicolumn{2}{|l|}{ Phone: } \\
\hline \multirow{3}{*}{$\begin{array}{l}\text { Additional } \\
\text { assessor (1) }\end{array}$} & \multicolumn{2}{|l|}{ Organisational affiliation: } \\
\hline & \multicolumn{2}{|l|}{ email: } \\
\hline & \multicolumn{2}{|l|}{ Phone: } \\
\hline \multirow{3}{*}{$\begin{array}{l}\text { Additional } \\
\text { assessor (2) }\end{array}$} & \multicolumn{2}{|l|}{ Organisational affiliation: } \\
\hline & \multicolumn{2}{|l|}{ email: } \\
\hline & \multicolumn{2}{|l|}{ Phone: } \\
\hline \multicolumn{3}{|c|}{ BAC3 Name(s) and contact details of expert(s) consulted } \\
\hline \multirow[t]{3}{*}{ Expert (1) } & \multicolumn{2}{|l|}{ Name: } \\
\hline & \multicolumn{2}{|l|}{ email: } \\
\hline & \multicolumn{2}{|l|}{ Phone: } \\
\hline \multirow[t]{3}{*}{ Expert (2) } & \multicolumn{2}{|l|}{ Name: } \\
\hline & \multicolumn{2}{|l|}{ email: } \\
\hline & \multicolumn{2}{|l|}{ Phone: } \\
\hline \multicolumn{3}{|l|}{ Comments: } \\
\hline \multicolumn{3}{|c|}{ BAC4 Scientific name of Taxon under assessment } \\
\hline \multicolumn{2}{|l|}{ Taxon name: } & Authority: \\
\hline \multicolumn{3}{|l|}{ Comments: } \\
\hline \multicolumn{3}{|l|}{ References: } \\
\hline BAC5 Synonyr & (s) considered & \\
\hline Synonyms: & & \\
\hline Comments: & & \\
\hline References: & & \\
\hline BAC6 Commo & name(s) considered & \\
\hline Common name & & \\
\hline Comments: & & \\
\hline References: & & \\
\hline
\end{tabular}


BAC7 What is the native range of the Taxon? (add map in Appendix BAC7)

\begin{tabular}{l|l}
\hline Response: & Confidence: \\
\hline Comments: &
\end{tabular}

References:

BAC8 What is the global alien range of the Taxon? (add map in Appendix BAC8)

Response:

Confidence:

Comments:

References:

BAC9 Geographic scope $=$ the Area under consideration

Area of assessment:

Comments:

BAC10 Is the Taxon present in the Area?

Response:

Confidence:

Comments:

References:

BAC11 Availability of physical specimen

Response:

Confidence in ID:

Herbarium or museum accession number:

References:

BAC12 Is the Taxon native to the Area or part of the Area?

\begin{tabular}{l|l|l|}
\hline $\begin{array}{l}\text { The Taxon is native to } \\
\text { (part of) the Area. }\end{array}$ & Yes / No / Don't know & Confidence: \\
\hline $\begin{array}{l}\text { The Taxon is alien in } \\
\text { (part of) the Area. }\end{array}$ & Yes / No / Don't know & Confidence: \\
\hline
\end{tabular}

Comments:

References:

BAC13 What is the Taxon's introduction status in the Area?

\begin{tabular}{l|l|l|}
\hline $\begin{array}{l}\text { The Taxon is in } \\
\text { cultivation/containment. }\end{array}$ & Yes / No / Don't know & Confidence: \\
\hline $\begin{array}{l}\text { The Taxon is present } \\
\text { outside of } \\
\text { cultivation/containment. }\end{array}$ & Yes / No / Don't know & Confidence: \\
\hline $\begin{array}{l}\text { The Taxon has } \\
\text { established/naturalised. }\end{array}$ & Yes / No / Don't know & Confidence: \\
\hline $\begin{array}{l}\text { The Taxon is invasive. } \\
\text { Comments: }\end{array}$ & Yes / No / Don't know & Confidence: \\
\hline References: & \\
\hline BAC14 Primary (introduction) pathways \\
\hline
\end{tabular}




\begin{tabular}{|l|l|l|}
\hline Release & Confidence: \\
\hline Escape & Confidence: \\
\hline Contaminant & Confidence: \\
\hline Stowaway & Confidence: \\
\hline Corridor & Confidence: \\
\hline Unaided & Confidence: \\
\hline Comments: & \\
\hline References: & \\
\hline
\end{tabular}




\section{Likelihood}

LIK1 Likelihood of entry via unaided primary pathways

Response:

Confidence:

Rationale:

References:

\section{LIK2 Likelihood of entry via human aided primary pathways}

Response:

Confidence:

Rationale:

References:

\begin{tabular}{|l|l|}
\hline LIK3 Habitat suitability \\
\hline Response: & \\
\hline Rationale: & Confidence: \\
\hline References: & \\
\hline
\end{tabular}

\begin{tabular}{|l|l|}
\hline LIK4 Climate suitability \\
\hline Response: & Confidence: \\
\hline Rationale: & \\
\hline References: & \\
\hline
\end{tabular}

\begin{tabular}{|l|l|}
\hline LIK5 Unaided secondary (dispersal) pathways & \\
\hline Response: & Confidence: \\
\hline Rationale: & \\
\hline References: & \\
& \\
\hline
\end{tabular}

\begin{tabular}{|l|l|}
\hline LIK6 Human aided secondary (dispersal) pathways & \multicolumn{2}{|l|}{} \\
\hline Response: & Confidence: \\
\hline Rationale: & \\
\hline References: & \\
\end{tabular}




\section{Consequences}

IMP1 Environmental impact (Figure 3)

Response:

Confidence:

Rationale:

References:

\section{IMP1a: Competition}

Response:

Confidence:

Rationale:

References:

IMP1b: Predation

Response:

Confidence:

Rationale:

References:

IMP1c: Hybridisation

Response:

Confidence:

Rationale:

References:

\section{IMP1d: Transmission of disease}

Response:

Confidence:

Rationale:

References:

IMP1e: Parasitism

Response:

Confidence:

Rationale:

References:

IMP1f: Poisoning/toxicity

Response:

Confidence:

Rationale:

References:

\section{IMP1g: Bio-fouling}

Response:

Confidence:

Rationale:

References: 


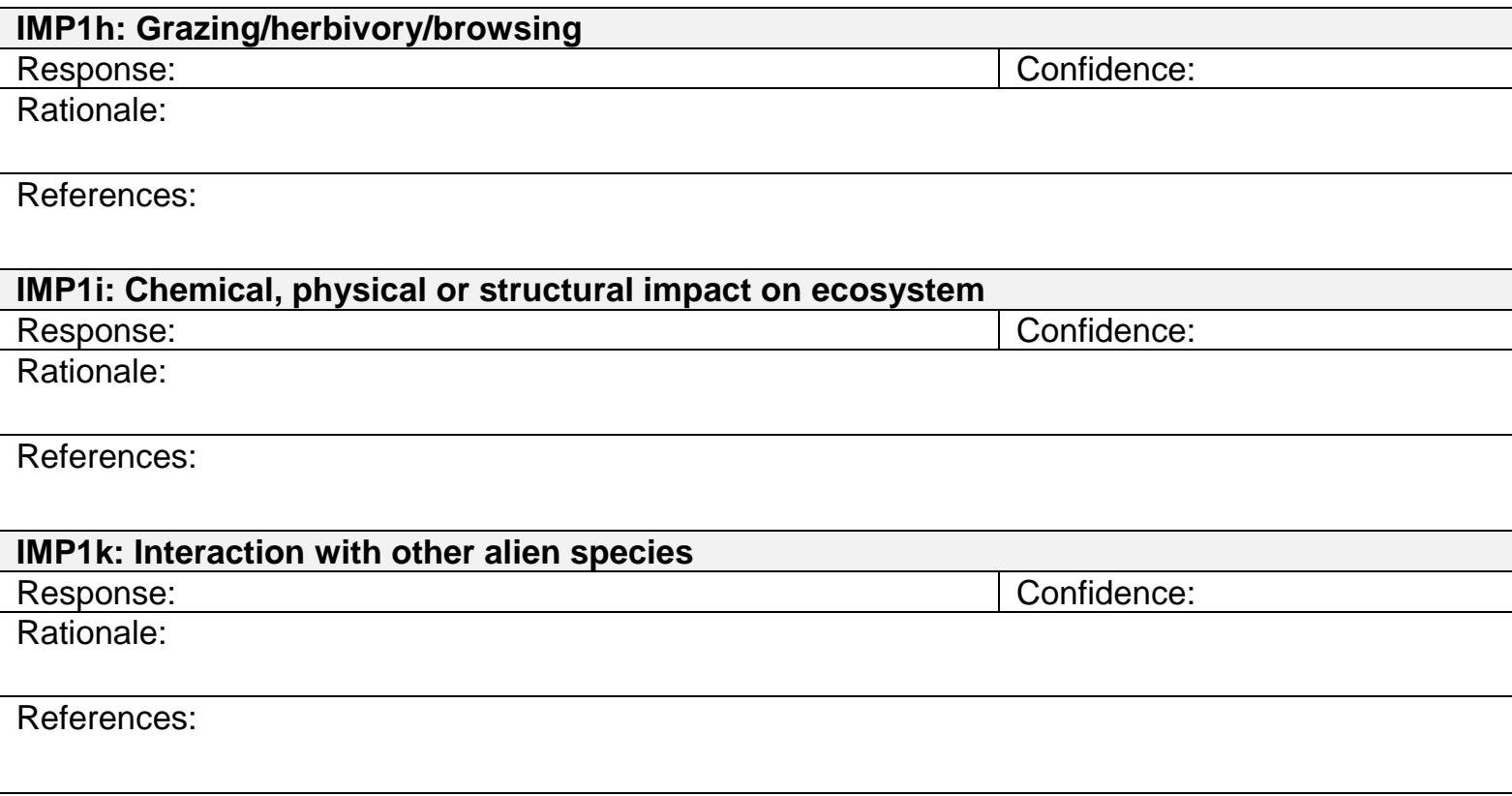

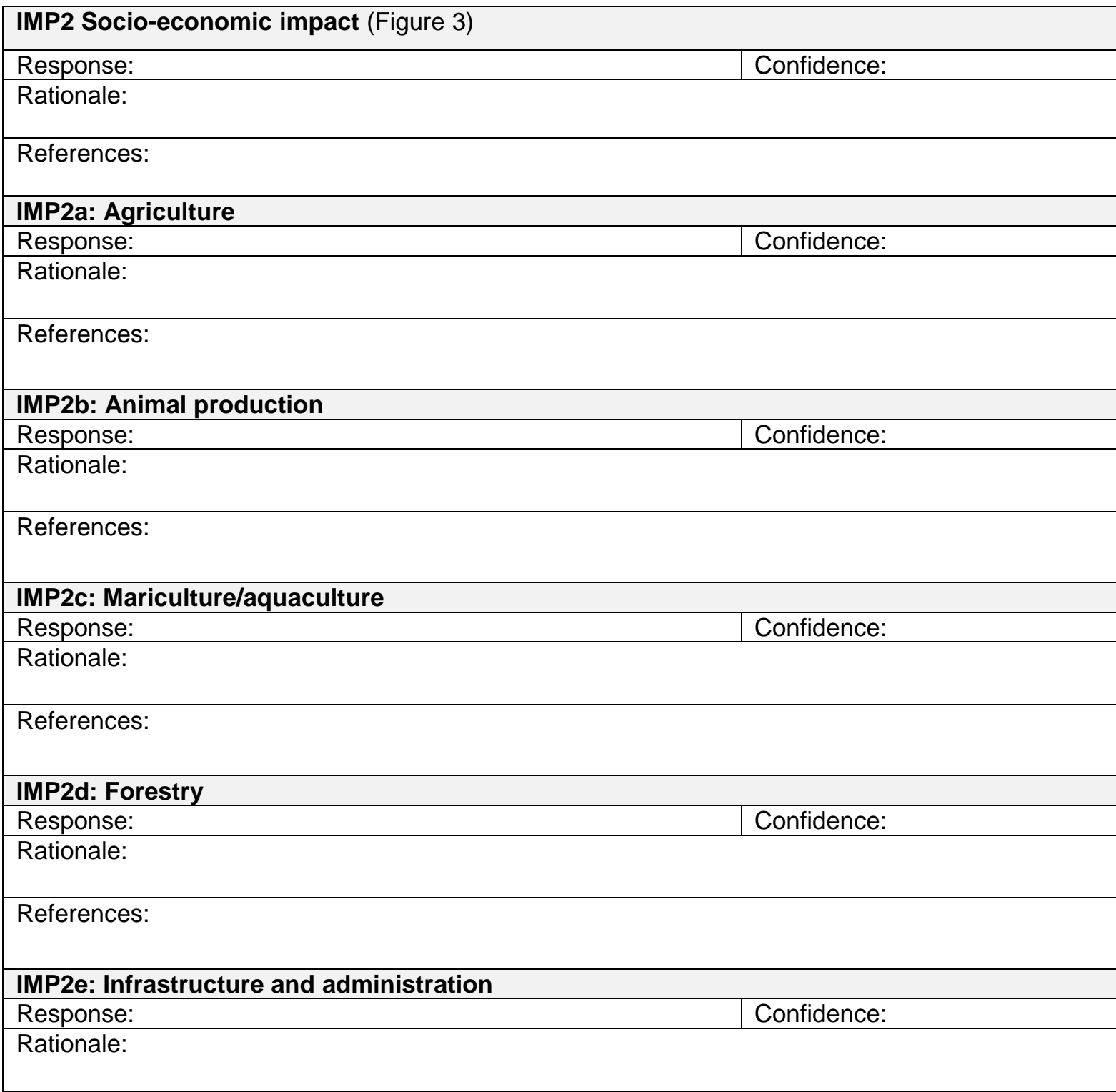


References:

IMP2f: Human health

Response:

Confidence:

Rationale:

References:

IMP2g: Human social life

Response:

Confidence:

Rationale:

References:

IMP3 Closely related species' environmental impact

Response:

Confidence:

Rationale:

References:

IMP4 Closely related species' socio-economic impact

Response:

Confidence:

Rationale:

References:

\section{IMP5 Potential impact}

Response:

Confidence:

Rationale:

References: 


\section{Management}

MAN1 What is the feasibility to stop future immigration?

Response: Confidence:

Rationale:

References:

\begin{tabular}{|l|l|}
\hline \multicolumn{2}{|l|}{ MAN2 Benefits of the Taxon } \\
\hline MAN2a Socio-economic benefits of the Taxon \\
\hline Response: & \multicolumn{2}{|l|}{} \\
\hline Rationale: & \multicolumn{2}{|l|}{} \\
\hline References: & \\
\hline MAN2b Environmental benefits of the Taxon \\
\hline Response: & Confidence: \\
\hline Rationale: & \\
\hline References:
\end{tabular}

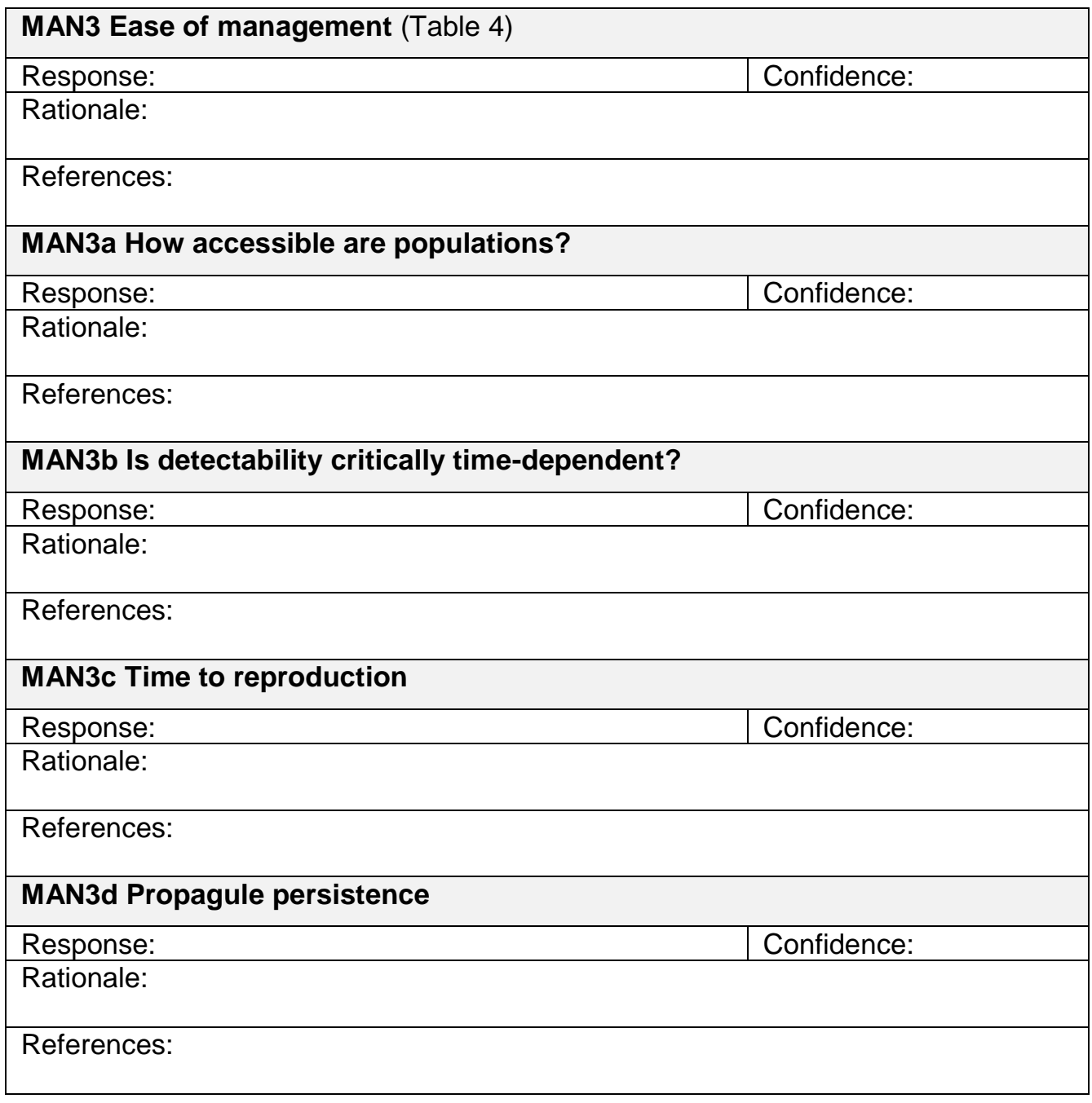


MAN4 Has the feasibility of eradication been evaluated?

Response:

Confidence:

Rationale:

References: 


\section{Calculations}

Likelihood $=$

\begin{tabular}{|l|l|l|l|}
\hline Parameter & Likelihood & Stages & Final assessment \\
\hline LIK1 & & $\mathrm{P}($ entry $)=$ & \\
\hline LIK2 & & $\mathrm{P}($ establishment $)=$ & \multirow{2}{*}{$\mathrm{P}$ (invasion) $=$} \\
\hline LIK3 & & $\mathrm{P}($ spread $)=$ & \\
\hline LIK4 & & & \\
\hline LIK5 & & & \\
\hline LIK6 & &
\end{tabular}

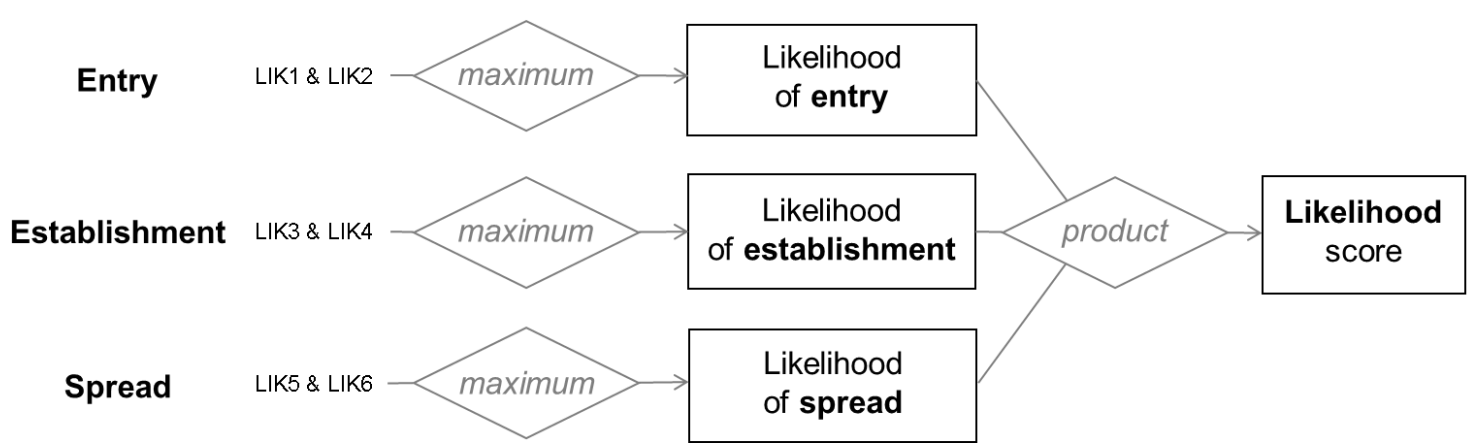

Figure 2 The calculation of a final likelihood score from the likelihood questions LIK1-LIK6. Use the probabilities indicated in the guidelines for calculations. The likelihood descriptions to extract a Risk score for the Risk assessment in Table 3 can then be found in Table 2. Alternatively, see Appendix 5 for calculation of the final likelihood score directly from the answers given.

Table 2: Transcription of Likelihood scores into descriptions for the Risk score in Table 3. The Likelihood score is calculated as in Figure 2.

\begin{tabular}{|l|l|}
\hline Likelihood score & Likelihood (description) \\
\hline$<0.000001$ & Extremely unlikely \\
\hline $0.000001 \leq p<0.0027$ & Very unlikely \\
\hline $0.0027 \leq p<0.027$ & Unlikely \\
\hline $0.027 \leq p<0.5$ & Fairly probable \\
\hline$p \geq 0.5$ & Probable \\
\hline
\end{tabular}




\section{Consequence $=$}

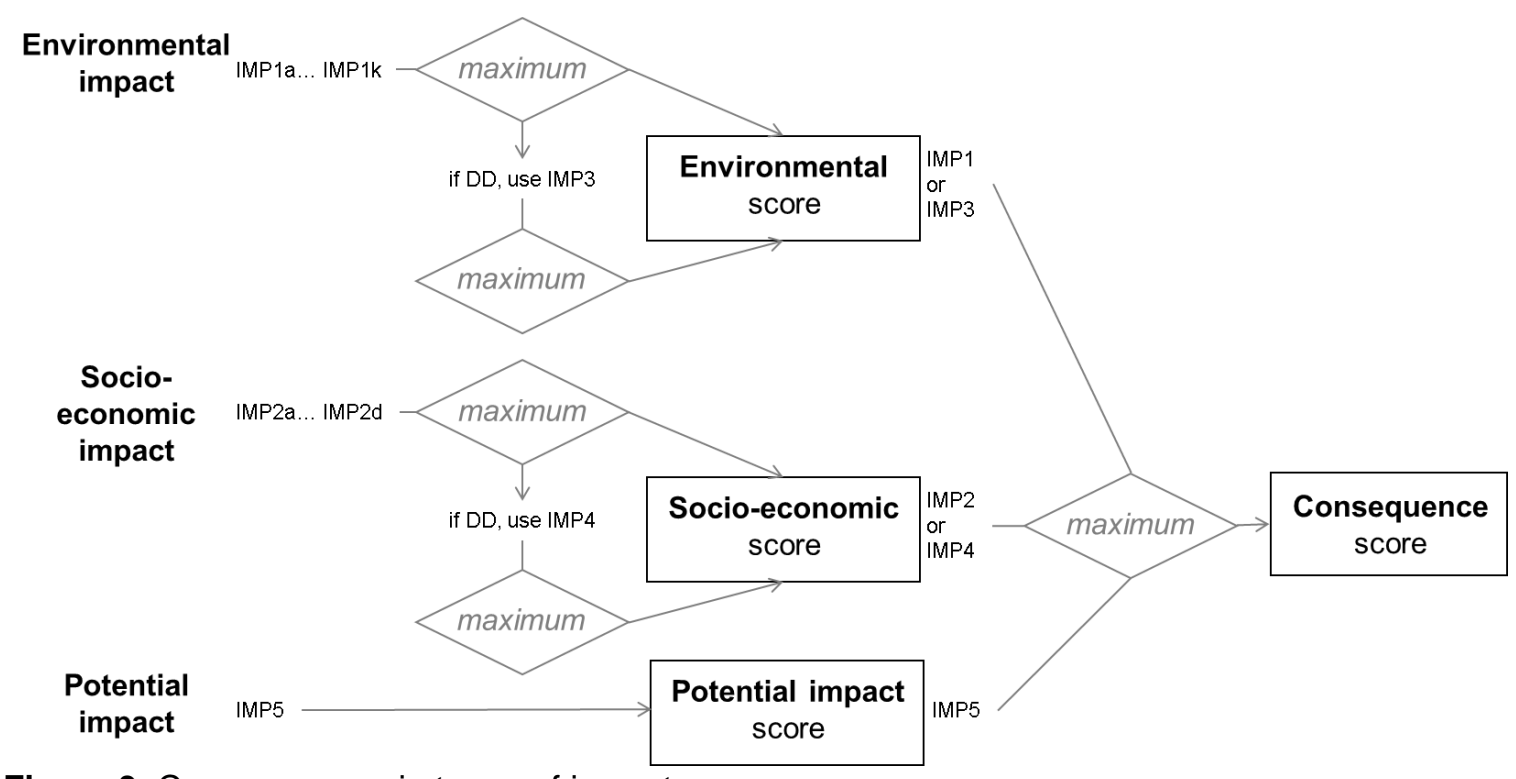

Figure 3: Consequences in terms of impact scores

\begin{tabular}{|l|l|l|}
\hline Parameter & Mechanism/sector & Response \\
\hline IMP1a & Competition & \\
\hline IMP1b & Predation & \\
\hline IMP1c & Hybridisation & \\
\hline IMP1d & Disease transmission & \\
\hline IMP1e & Parasitism & \\
\hline IMP1f & Poisoning/toxicity & \\
\hline IMP1g & Bio-fouling & \\
\hline IMP1h & Grazing/herbivory/browsing & \\
\hline IMP1i & Chemical, physical, structural impact & \\
\hline IMP1k & Interaction with other aliens & \\
\hline IMP2a & Agriculture & \\
\hline IMP2b & Animal production & \\
\hline IMP2c & Mariculture/aquaculture & \\
\hline IMP2d & Forestry & \\
\hline IMP2e & Infrastructure & \\
\hline IMP2f & Human health & \\
\hline IMP2g & Human social life & \\
\hline
\end{tabular}

\section{Risk =}

Table 3: Risk assessment outcomes considering likelihood (Figure 2 and Table 2) and consequences (outcome of Figure 3), leading to a Risk score. Highlight the respective levels for your Taxon in the table.

\begin{tabular}{|c|c|c|c|c|c|c|}
\hline & \multicolumn{5}{|c|}{ Consequences } \\
\hline & & MC & MN & MO & MR & MV \\
\hline \multirow{5}{*}{ 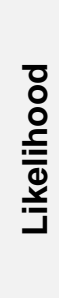 } & Extremely unlikely & low & low & low & medium & medium \\
\hline & Very unlikely & low & low & low & medium & high \\
\hline & Unlikely & low & low & medium & high & high \\
\hline & Fairly probable & medium & medium & high & high & high \\
\hline & Probable & medium & high & high & high & high \\
\hline
\end{tabular}




\section{Ease of management $=$}

Table 4: Ease of management of a Taxon which is present in the Area (modified from Wilson et al. 2017). Fill in the responses from MAN3a-MAN3d and sum up the numbers for MAN3.

\begin{tabular}{|c|l|c|}
\hline Parameter & \multicolumn{1}{|c|}{ Question } & Response \\
\hline MAN3a & How accessible are populations? & \\
\hline MAN3b & Is detectability critically time-dependent? & \\
\hline MAN3c & Time to reproduction & \\
\hline MAN3d & Propagule persistence & \\
\hline MAN3 & SUM & \\
\hline
\end{tabular}




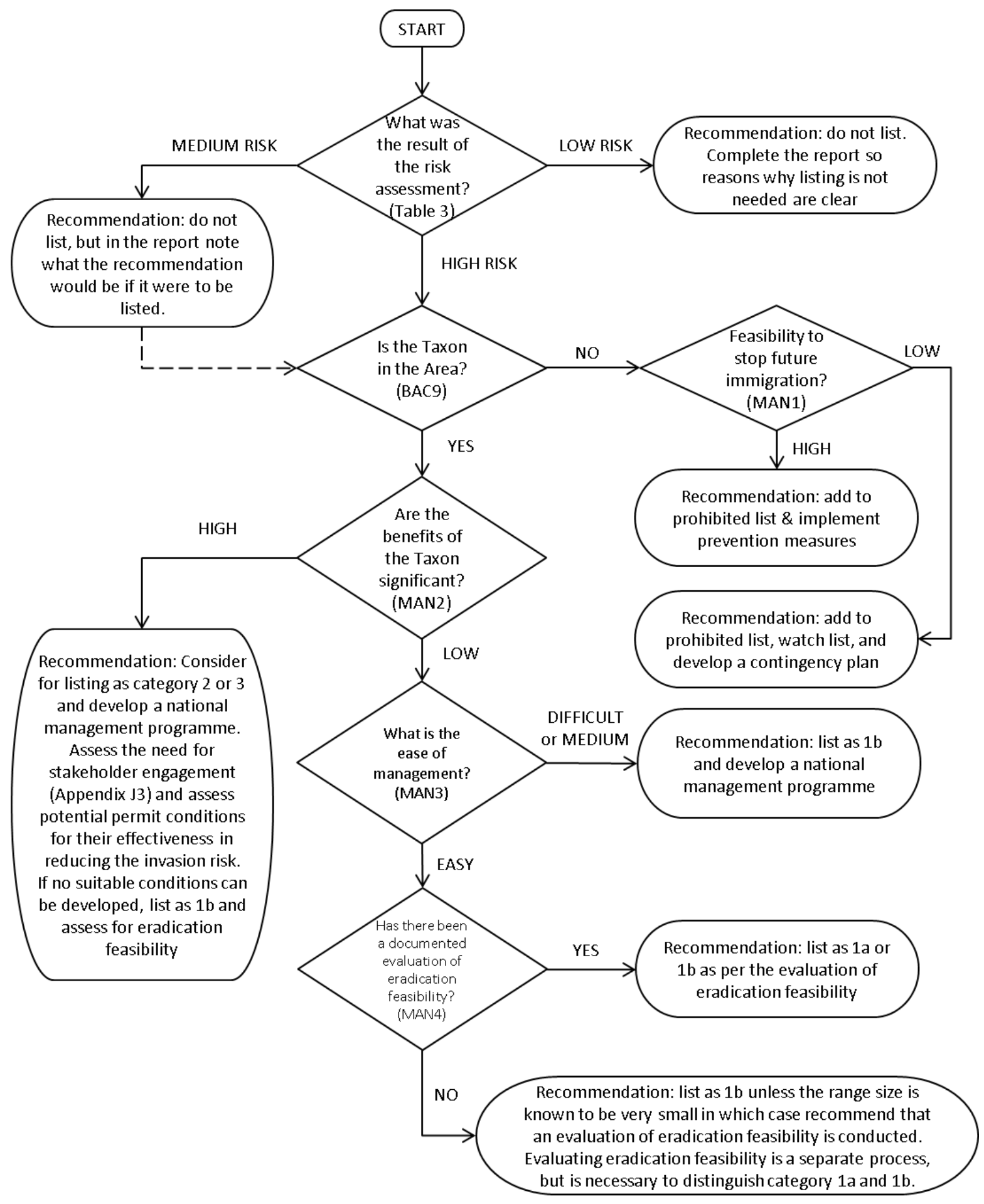

Figure 4. A decision tree for determining the appropriate risk management response. The listing categories (1a, 1b, 2 and 3) are as per South Africa's NEMBA Regulations.

There are several additional considerations that will need to be made when drafting management plans, for instance:

- Will stakeholders be opposed to management (e.g. access to land)?

- $\quad$ Are control efforts ethical (in particular for vertebrates)?

- Might it be feasible to contain populations?

- $\quad$ Should resources be spent to develop new control measures (e.g. biological control)?

Such issues are important when attempting to reduce and mitigate the risks caused, but need to be considered explicitly outside of the current framework. 


\section{Supplementary to add to answer sheet}

Appendix BAC7: Provide here a map of the native range, if possible. If the map is available in a file, please insert a low res copy $(<1 \mathrm{MB})$ and provide the file name and (if possible) a link to a higher resolution copy below. 
Appendix BAC8: Provide here a map of the global alien range, including the range within the Area, if possible. If the map is available in a file, please insert a low res copy $(<1 \mathrm{MB})$ and provide the file name and (if possible) a link to a higher resolution copy below. 


\section{Annexure 1: Glossary}

NEMBA Regulations: The National Environmental Management: Biodiversity Act (NEMBA, Act 10 of 2004) Alien and Invasive Species Regulations (Department of Environmental Affairs 2014)

Alien taxon: A taxon in a given area whose presence there is due to intentional or accidental introduction as a result of human activity. Taxa that have part of their native range in a given country, but whose presence in another part of the same country is attributable to human actions that enabled the taxon to overcome fundamental biogeographical barriers, are also referred to as alien here.

Area: The area of assessment for the risk analysis. Specify the geographic entity under consideration, i.e. the geographic scope of the assessment. In most cases this will be the whole of South Africa, but can also be only a part of the country, for example a single province, a national park or a river catchment. The region under assessment will be referred to as the Area in the framework.

Extralimital: A taxon that has part of their native range in a given country, but whose presence in another part of the same country is attributable to human actions that enabled the taxon to overcome fundamental biogeographical barriers

Invasive taxon: A taxon which is alien to an area and which has self-sustaining populations there with propagules spreading from the initial site of introduction.

Pathway: The processes by which taxa are moved between areas.

Primary (introduction) pathway: The combined processes by which taxa are introduced from one geographical location to another (cf. Vector). Classified into categories and subcategories as outlined in Appendix S3.

Propagule: any spore, seed, fruit, fragment, or other part of an organism capable of reproduction by sexual or asexual means that is dispersed (accidentally or deliberately)

Secondary (dispersal) pathway: The processes by which taxa disperse or are dispersed from one area of introduction to another.

Risk analysis: The process of identifying and assessing the likelihood and consequence of an event, as well as considerations as to manage and communicate the risks.

Risk assessment: The process of evaluating the likelihood and consequence of an event taking place. In this document, such an event would be an alien taxon becoming a harmful invasive species. Risk assessment is part of risk analysis. Risk analysis is comprised of risk assessment, risk management and risk communication.

Risk management: The process of assessing options by which the risks of an event (its likelihood and/or consequence) can be reduced or mitigated.

Introduction status: Whether a taxon is found in an area to which it is not native (alien), and how far along the introduction-naturalisation-invasion continuum it has reached. Ideally as per the Blackburn et al. (2011) framework (Appendix S4)

Vector: A mechanism responsible for the transport of species to new areas where they did not previously occur. A pathway (for example shipping) could have several vectors associated with it (for example in cargo, in passenger luggage, on passengers or crew themselves, in ballast water, or attached to the hull). 


\section{Supporting Material \\ Appendix S0: How the Risk Analysis Framework covers Section 6, Regulation 14-17, in the NEM:BA A\&IS Regulations of 2014}

The proposed Risk Analysis Framework is intended for collation of evidence for the listing of species under the NEM:BA A\&IS Regulations (DEA 2014). It covers all aspects of Reg. 14, as well as some of Reg. 17 (Table S1), except the ones which are specifically related to permits (Table S2). Some additional information is included in the framework. Furthermore, it allows for a transparent documentation and decision making process, as standardized answers are given with clear descriptions.

Information concern restricted activity related to permit applications is not included in the framework but can easily be requested in a separate document (Table S2). In future, when all species listed under the Regulations will have been assessed with the Risk Analysis Framework, it will only be necessary for permit applicants to fill in this extra document on the restricted activity. This is more specific to the restricted activity and the area in which this will be carried out, but some aspects collected for the main Risk Analysis could be used to do these assessments, e.g. 14(1)(c)(i).

Table S1: Questions in the Risk Analysis Framework, and which aspects in the NEMBA Regulations they cover

\begin{tabular}{|c|c|c|}
\hline Parameter & Question & NEMBA \\
\hline BAC1 & Name of assessor(s) & $\begin{array}{l}\text { 17. (1) } \\
\text { (a) The personal details and qualifications of the risk } \\
\text { assessment practitioner carrying out the risk } \\
\text { assessment }\end{array}$ \\
\hline BAC2 & $\begin{array}{l}\text { Contact details of } \\
\text { assessor(s) }\end{array}$ & $\begin{array}{l}\text { 17. (1) } \\
\text { (a) The personal details and qualifications of the risk } \\
\text { assessment practitioner carrying out the risk } \\
\text { assessment }\end{array}$ \\
\hline BAC3 & $\begin{array}{l}\text { Name(s) and contact } \\
\text { details of expert(s) } \\
\text { consulted }\end{array}$ & $\begin{array}{l}\text { 17. (1) } \\
\text { (b) the personal details and qualifications of the expert } \\
\text { consulted as required in regulation } 15(3)(e)\end{array}$ \\
\hline BAC4 & $\begin{array}{l}\text { Scientific name of } \\
\text { Taxon under } \\
\text { assessment }\end{array}$ & $\begin{array}{l}\text { 14. (1) } \\
\text { (a) (i) the taxonomy of the species, including its class, } \\
\text { order, family, scientific name if known, genus, scientific } \\
\text { synonyms and common names of the species }\end{array}$ \\
\hline BAC5 & Synonym(s) considered & $\begin{array}{l}\text { 14. (1) } \\
\text { (a) (i) the taxonomy of the species, including its class, } \\
\text { order, family, scientific name if known, genus, scientific } \\
\text { synonyms and common names of the species }\end{array}$ \\
\hline BAC6 & $\begin{array}{l}\text { Common name(s) } \\
\text { considered }\end{array}$ & $\begin{array}{l}\text { 14. (1) } \\
\text { (a) (i) the taxonomy of the species, including its class, } \\
\text { order, family, scientific name if known, genus, scientific } \\
\text { synonyms and common names of the species }\end{array}$ \\
\hline BAC7 & $\begin{array}{l}\text { What is the native range } \\
\text { of the Taxon? }\end{array}$ & $\begin{array}{l}\text { 14. (1) } \\
\text { (a) (ii) the originating environment of the species, } \\
\text { including climate, extent of geographic range and } \\
\text { trends }\end{array}$ \\
\hline
\end{tabular}




\begin{tabular}{|c|c|c|}
\hline Parameter & Question & NEMBA \\
\hline BAC8 & $\begin{array}{l}\text { What is the global alien } \\
\text { range of the Taxon? }\end{array}$ & $\begin{array}{l}\text { 14. (1) } \\
\text { (a) (ii) the originating environment of the species, } \\
\text { including climate, extent of geographic range and } \\
\text { trends } \\
\text { (v) the history of domestic propagation or cultivation of } \\
\text { the species, introductions and the extent of } \\
\text { naturalisation in South Africa and elsewhere }\end{array}$ \\
\hline BAC9 & $\begin{array}{l}\text { Geographic scope }=\text { the } \\
\text { Area under } \\
\text { consideration }\end{array}$ & \\
\hline BAC10 & $\begin{array}{l}\text { Is the Taxon present in } \\
\text { the Area? }\end{array}$ & $\begin{array}{l}\text { 14. (1) } \\
\text { (a) (v) the history of domestic propagation or cultivation } \\
\text { of the species, introductions and the extent of } \\
\text { naturalisation in South Africa and elsewhere }\end{array}$ \\
\hline BAC11 & $\begin{array}{l}\text { Availability of physical } \\
\text { specimen }\end{array}$ & \\
\hline BAC12 & $\begin{array}{l}\text { Is the Taxon native to } \\
\text { the Area or part of the } \\
\text { Area? }\end{array}$ & $\begin{array}{l}\text { 14. (1) } \\
\text { (a) (v) the history of domestic propagation or cultivation } \\
\text { of the species, introductions and the extent of } \\
\text { naturalisation in South Africa and elsewhere }\end{array}$ \\
\hline BAC13 & $\begin{array}{l}\text { What is the Taxon's } \\
\text { introduction status in the } \\
\text { Area? }\end{array}$ & $\begin{array}{l}\text { 14. (1) } \\
\text { (a) (v) the history of domestic propagation or cultivation } \\
\text { of the species, introductions and the extent of } \\
\text { naturalisation in South Africa and elsewhere }\end{array}$ \\
\hline BAC14 & $\begin{array}{l}\text { Primary (introduction) } \\
\text { pathways }\end{array}$ & \\
\hline LIK1 & $\begin{array}{l}\text { Likelihood of entry via } \\
\text { unaided primary } \\
\text { pathways }\end{array}$ & $\begin{array}{l}\text { 14. (1) } \\
\text { (a) (iii) persistence attributes of the species, including } \\
\text { reproductive potential, mode of reproduction, dispersal } \\
\text { mechanisms and undesirable traits }\end{array}$ \\
\hline LIK2 & $\begin{array}{l}\text { Likelihood of entry via } \\
\text { human aided primary } \\
\text { pathways }\end{array}$ & \\
\hline LIK3 & Habitat suitability & $\begin{array}{l}\text { 14. (1) } \\
\text { (a) (ii) the originating environment of the species, } \\
\text { including climate, extent of geographic range and } \\
\text { trends } \\
\text { (vi) nutritional or dietary requirements of the species } \\
\text { and, where applicable, whether it has a specialist or } \\
\text { generalist diet } \\
\text { (c) (ii) habitat } \\
\text { (iii) disturbance regimes } \\
\text { (iv) the presence of natural enemies, predators and } \\
\text { competitors }\end{array}$ \\
\hline LIK4 & Climate suitability & $\begin{array}{l}\text { 14. (1) } \\
\text { (c) (i) climate match }\end{array}$ \\
\hline LIK5 & $\begin{array}{l}\text { Unaided secondary } \\
\text { (dispersal) pathways }\end{array}$ & $\begin{array}{l}\text { 14. (1) } \\
\text { (a) (iii) persistence attributes of the species, including } \\
\text { reproductive potential, mode of reproduction, dispersal } \\
\text { mechanisms and undesirable traits }\end{array}$ \\
\hline LIK6 & $\begin{array}{l}\text { Human aided secondary } \\
\text { (dispersal) pathways }\end{array}$ & \\
\hline
\end{tabular}




\begin{tabular}{|c|c|c|}
\hline Parameter & Question & NEMBA \\
\hline IMP1 & Environmental impact & $\begin{array}{l}\text { 14. (1) } \\
\text { (a) (vii) the ability of the species to create significant } \\
\text { change in an ecosystem; } \\
\text { (viii) the potential to hybridise with other species and to } \\
\text { produce fertile hybrids }\end{array}$ \\
\hline IMP2 & Socio-economic impact & $\begin{array}{l}\text { 14. (1) } \\
\text { (a) (vii) the ability of the species to create significant } \\
\text { change in an ecosystem }\end{array}$ \\
\hline IMP3 & $\begin{array}{l}\text { Closely related species' } \\
\text { environmental impact }\end{array}$ & $\begin{array}{l}\text { 14. (1) } \\
\text { (a) (iv) invasive tendencies of the species elsewhere } \\
\text { and of close taxonomic relatives in South Africa and } \\
\text { elsewhere }\end{array}$ \\
\hline IMP4 & $\begin{array}{l}\text { Closely related species' } \\
\text { socio-economic impact }\end{array}$ & $\begin{array}{l}\text { 14. (1) } \\
\text { (a) (iv) invasive tendencies of the species elsewhere } \\
\text { and of close taxonomic relatives in South Africa and } \\
\text { elsewhere }\end{array}$ \\
\hline IMP5 & Potential impact & $\begin{array}{l}\text { 14. (1) } \\
\text { (a) (iii) persistence attributes of the species, including } \\
\text { reproductive potential, mode of reproduction, dispersal } \\
\text { mechanisms and undesirable traits } \\
\text { (vi) nutritional or dietary requirements of the species } \\
\text { and, where applicable, whether it has a specialist or } \\
\text { generalist diet } \\
\text { (c) (v) the presence of potentially reproductive } \\
\text { compatible species } \\
\text { (2) } \\
\text { (b) the possible impact of the species on the } \\
\text { biodiversity and sustainable use of natural resources } \\
\text { of- (ii) in any other area elsewhere in the Republic } \\
\text { (c) the risks of the specimen serving as a vector } \\
\text { through which specimens of other alien species may } \\
\text { be introduced }\end{array}$ \\
\hline MAN1 & $\begin{array}{l}\text { What is the feasibility of } \\
\text { stopping future } \\
\text { immigration? }\end{array}$ & $\begin{array}{l}\text { (2) (e) any measures proposed in order to manage the } \\
\text { risks }\end{array}$ \\
\hline MAN2 & Benefits of the Taxon & $\begin{array}{l}\text { 17. (1) } \\
\text { (d) key economic, social and ecological considerations } \\
\text { that will guide a decision on whether or not to issue a } \\
\text { permit }\end{array}$ \\
\hline MAN3 & Eradication feasibility & $\begin{array}{l}(2)(e) \text { any measures proposed in order to manage the } \\
\text { risks }\end{array}$ \\
\hline
\end{tabular}

\section{Conclusions in framework:}

(3) Based on the information in sub-regulations (1) and (2), a risk assessment must consider-

(a) the likelihood of the risks being realised;

(b) the severity of the risks and consequences of the realisation of the risks for other species, habitats and ecosystems;

(c) the potential costs associated with the control of the species to minimise harm to biodiversity; and

(d) options for minimising the potential risks 
Table S2: Aspects not covered in the Risk Analysis Framework which deal with the restricted activity regarding the permit application and are suggested to be requested for permit applications in a separate document

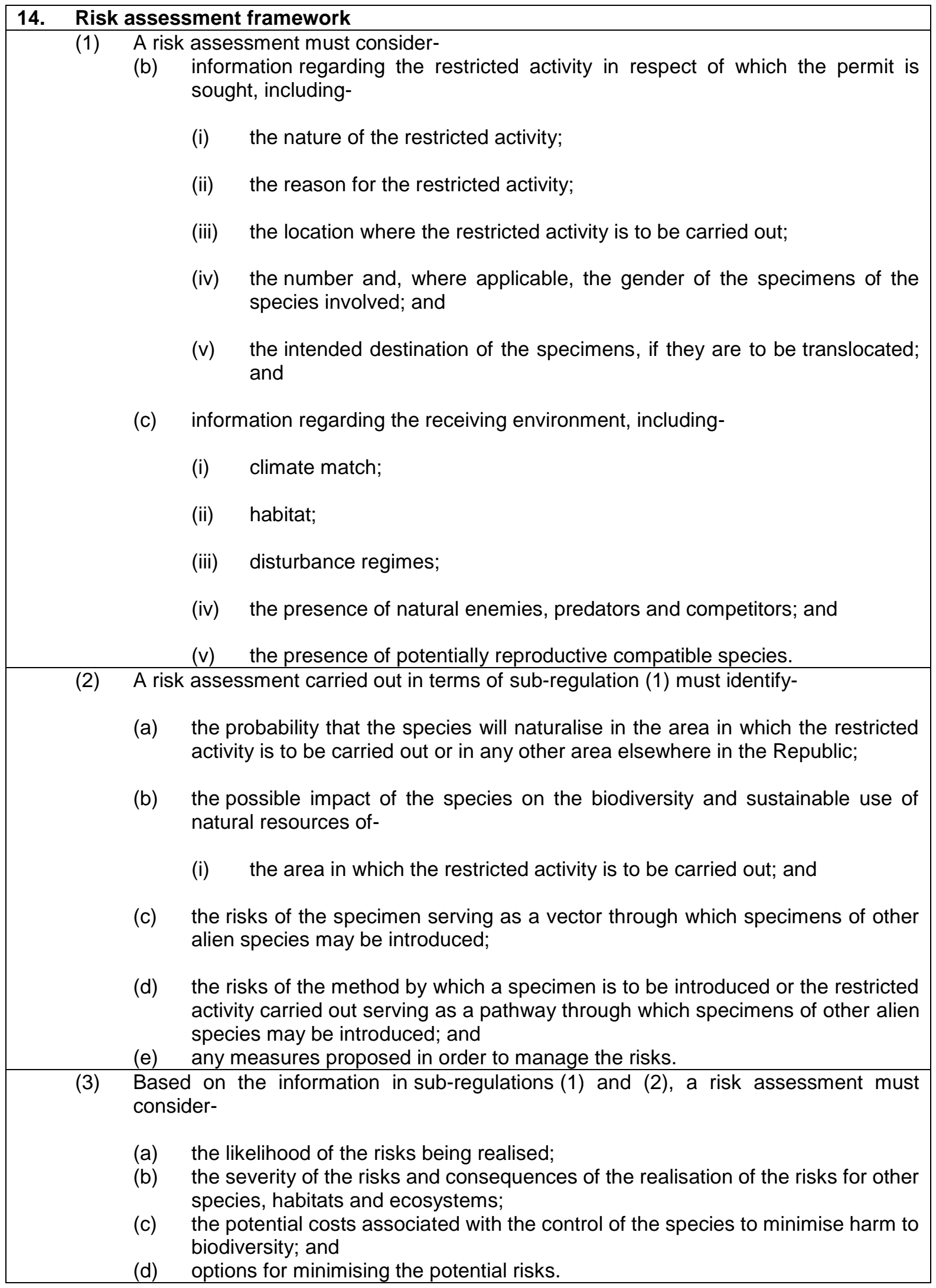


Appendix S1: Sources of information which can be used for the risk analysis. This is not an exhaustive list, but provides a starting point on where to search for information. This table is taken from Marais, Richardson \& Davies (2012) Risk assessments for invasive species in South Africa: Sources of information. Draft Report submitted to DEA on 31 October.

Additionally, consider atlases and other distribution databases, like for example SABAP2 (Southern African Bird Atlas Project; http://sabap2.adu.org.za/), SAPIA, the Red List of Threatened Species (http://www.iucnredlist.org/), and other databases on alien species (e.g., http://www.griis.org/ ; http://www.europe-aliens.org/ )

Key to colouring of cells

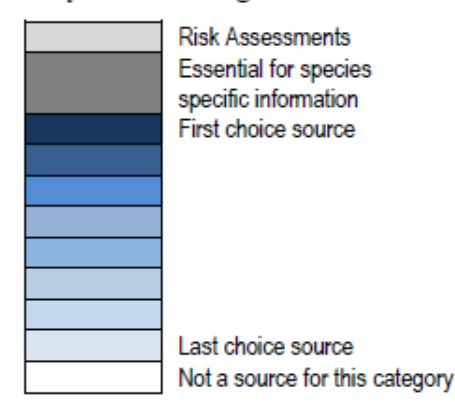

\begin{tabular}{|c|c|c|c|c|c|c|c|c|}
\hline Taxon/Group & Source & Source type & Reference & Synonyms & $\begin{array}{l}\text { Invasive } \\
\text { Elsewhere? } \\
\text { Established } \\
\text { Elsewhere? }\end{array}$ & Impacts & $\begin{array}{l}\text { Nativel } \\
\text { Indigenous } \\
\text { range }\end{array}$ & $\begin{array}{l}\text { Ecologyl } \\
\text { Life history }\end{array}$ \\
\hline Plants & $\begin{array}{l}\text { Hawaiian Ecosystem at Risk (HEAR): Risk } \\
\text { Assessments }\end{array}$ & Website & http-J/www.hear.org/wral & & & & & \\
\hline All & Austral Ecology & $\begin{array}{l}\text { Peer-reviewed joumal with } \\
\text { many papers on invasive } \\
\text { species }\end{array}$ & $\begin{array}{l}\text { http-//onlinelibrary.wiley.com/Journal10.1111/(ISSN)1442- } \\
\text { g993/issues }\end{array}$ & & & & & \\
\hline All & Biodiversity and Conservation & $\begin{array}{l}\text { Peer-eviewed joumal with } \\
\text { many papers on invasive } \\
\text { species }\end{array}$ & http-//www.springerink.com/content $0960-3115 /$ & & & & & \\
\hline All & Biolinvasion Records & $\begin{array}{l}\text { Peer-reviewed joumal } \\
\text { focussing exclusively on } \\
\text { invasive species }\end{array}$ & http-//www.reabic.netjournals/bir/2012/ssue1.aspx & & & & & \\
\hline All & Biological Conservation & $\begin{array}{l}\text { Peer-reviewed joumal with } \\
\text { many papers on invasive } \\
\text { species }\end{array}$ & $\mathrm{http} / /$ www.sciencedirect.com/scienceljournal00063207 & & & & & \\
\hline
\end{tabular}




\begin{tabular}{|c|c|c|c|c|c|c|c|c|}
\hline Taxon/Group & Source & Source type & Reference & Synonyms & $\begin{array}{c}\text { Invasive } \\
\text { Elsewhere? } \\
\text { Established } \\
\text { Elsewhere? }\end{array}$ & Impacts & $\begin{array}{c}\text { Nativel } \\
\text { Indigenous } \\
\text { range }\end{array}$ & $\begin{array}{l}\text { Ecologyl } \\
\text { Life history }\end{array}$ \\
\hline species & & & & & & & & \\
\hline Arthropods & $\begin{array}{l}\text { North American Non-Indigenous Arthropod } \\
\text { Database (NANIAD) }\end{array}$ & Website & http-J/www.invasivespecies.org/NANIAD.html & & & & & \\
\hline Birds & $\begin{array}{l}\text { Introduced birds of the world: the worldwide } \\
\text { history, distribution, and influence of birds } \\
\text { introduced to new environments }\end{array}$ & Reference Book & Long 1981 & & & & & \\
\hline Birds & Naturalized birds of the world & Reference Book & Lever 1987 & & & & & \\
\hline $\begin{array}{l}\text { Freshwater } \\
\text { Fish }\end{array}$ & FishBase & Website & http-/fishbase.org/search.php & & & & & \\
\hline $\begin{array}{l}\text { Freshwater } \\
\text { Fish } \\
\end{array}$ & Naturalized fishes of the world & Reference Book & Lever 1996 & & & & & \\
\hline $\begin{array}{l}\text { Freshwater } \\
\text { taxa }\end{array}$ & $\begin{array}{l}\text { A handbook of global freshwater invasive } \\
\text { species }\end{array}$ & Reference Book & Francis 2011 & & & & & \\
\hline Mammals & $\begin{array}{l}\text { Introduced mammals of the world: their } \\
\text { history, distribution and influence }\end{array}$ & Primary Literature & Long 2003 & & & & & \\
\hline Mammals & $\begin{array}{l}\text { Mammal Species of the World. A Taxonomic } \\
\text { and Geographic Reference }\end{array}$ & Primary Literature & Wilson \& Reeder 2005 & & & & & \\
\hline Mammals & Naturalized mammals of the world & Reference Book & Lever 1985 & & & & & \\
\hline $\begin{array}{l}\text { Marine and } \\
\text { Freshwater } \\
\text { species }\end{array}$ & $\begin{array}{l}\text { National Exotic Marine and Estuarine } \\
\text { Species Information System (NEMESIS) }\end{array}$ & Website & http-J/invasions.si.edu/nemesis/ & & & & & \\
\hline $\begin{array}{l}\text { Marine } \\
\text { species }\end{array}$ & $\begin{array}{l}\text { Database of Global Marine Invasive Species } \\
\text { Threats }\end{array}$ & $\begin{array}{l}\text { Primary Literature: } \\
\text { Supplementary Material }\end{array}$ & Molnar et al. 2008 & & & & & \\
\hline $\begin{array}{l}\text { Marine } \\
\text { species }\end{array}$ & The Baltic Sea Alien Species Database & Website & httpJ//www.corpi.kultt/nemo/ & & & & & \\
\hline $\begin{array}{l}\text { Marine } \\
\text { species }\end{array}$ & World Register of Marine Species & Website & http.//www.marinespecies.org/ & & & & & \\
\hline Plants & A global compendium of weeds & Reference Book & Randall et al. 2012 & & & & & \\
\hline Plants & Australia's Virtual Herbarium & Website & http-l/avh.ala.org.au & & & & & \\
\hline Plants & CalFlora & Website & http $/ /$ www.calflora.org/ & & & & & \\
\hline
\end{tabular}

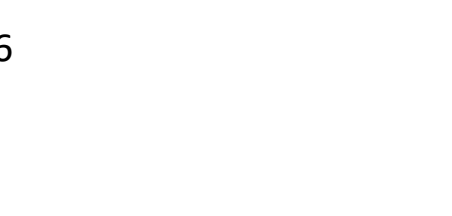

\section{西}

.

(1)

(1)

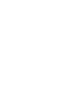

(n) 


\begin{tabular}{|c|c|c|c|c|c|c|c|c|}
\hline Taxon/Group & Source & Source type & Reference & Synonyms & $\begin{array}{l}\text { Invasive } \\
\text { Elsewhere?l } \\
\text { Established } \\
\text { Elsewhere? }\end{array}$ & Impacts & $\begin{array}{c}\text { Nativel } \\
\text { Indigenous } \\
\text { range }\end{array}$ & $\begin{array}{l}\text { Ecology/ } \\
\text { Life history }\end{array}$ \\
\hline Plants & Invasive plants of the World & Reference Book & Weber 2003 & & & & & \\
\hline $\begin{array}{ll}\text { Plants } \\
\end{array}$ & The Plant List & Website & http $/ /$ www.theplantist.org & & & & & \\
\hline Plants & $\begin{array}{l}\text { A new comprehensive database of alien } \\
\text { plant species in Chile based on herbarium } \\
\text { records }\end{array}$ & $\begin{array}{l}\text { Primary Literature: } \\
\text { Supplementary Material }\end{array}$ & Fuentes et al. 2012 & & & & & \\
\hline Reptiles & $\begin{array}{l}\text { A quantititive climate-match score for risk- } \\
\text { assessment screening of reptile and } \\
\text { amphibiain introductions }\end{array}$ & Primary Literature & Van Wilgen et al. 2009 & & & & & \\
\hline Reptles & The reptile database & Website & http $/ /$ www.reptile-database.org/ & & & & & \\
\hline $\begin{array}{l}\text { Reptiles and } \\
\text { Amphibians }\end{array}$ & $\begin{array}{l}\text { Alien reptiles and amphibians, a scientific } \\
\text { compendium and analyses }\end{array}$ & Reference Book & Kraus 2009 & & & & & \\
\hline
\end{tabular}

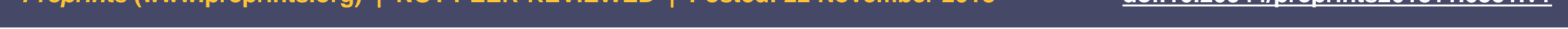

mpendium and analyses

7

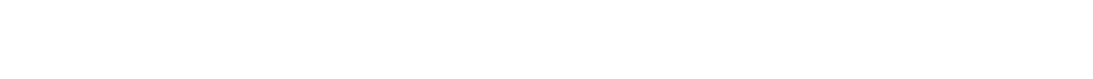

7


Appendix S2: Guidance regarding the use of the confidence rating (modified from the EPPO pest risk assessment decision support scheme (Alan MacLeod 09/03/2011; revised 28/04/2011; copied from CAPRA, version 2.74; 2)).

\section{Confidence Examples level}

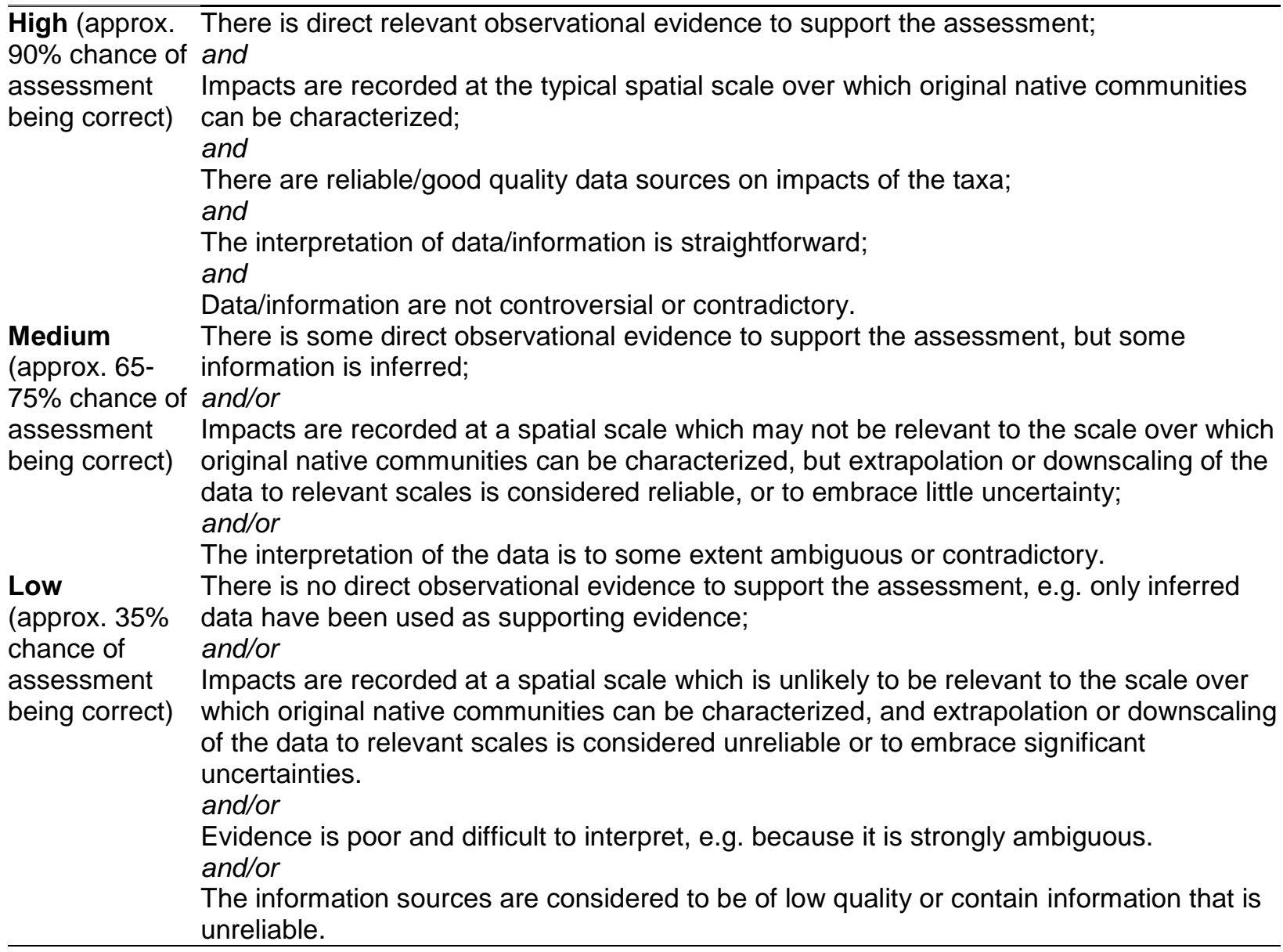


Appendix S3: Pathway categories and sub-categories (adapted from Essl et al. 2011)

\begin{tabular}{|c|c|}
\hline $\begin{array}{c}\text { Categ } \\
\text { ory }\end{array}$ & Subcategory \\
\hline \multirow{8}{*}{ 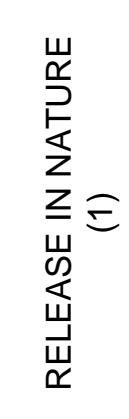 } & Biological control \\
\hline & Erosion control/ dune stabilization (windbreaks, hedges...) \\
\hline & Fishery in the wild \\
\hline & Hunting in the wild \\
\hline & Landscape/flora/fauna improvement \\
\hline & Conservation introduction \\
\hline & Release in nature for use (other than above, e.g. medical use, fur..) \\
\hline & Other Intentional release \\
\hline \multirow{12}{*}{ 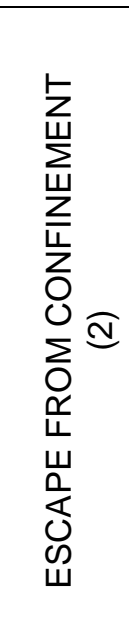 } & Agriculture (including biofuel feedstocks) \\
\hline & Aquaculture/mariculture \\
\hline & Botanical garden/zoo/aquaria (excluding domestic aquaria) \\
\hline & Farmed animals \\
\hline & Forestry \\
\hline & Fur farms \\
\hline & Horticulture \\
\hline & Ornamental purpose other than horticulture \\
\hline & Pet/aquarium/terrarium species \\
\hline & Research (in facilities) \\
\hline & Live food and live bait \\
\hline & Other escape from confinement \\
\hline \multirow{10}{*}{ 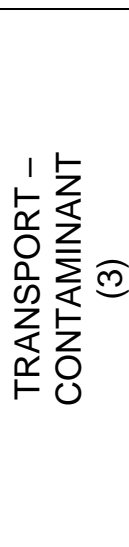 } & Contaminant nursery material \\
\hline & Contaminated bait \\
\hline & Food contaminant \\
\hline & Contaminant on animals (except species transported by host/vector) \\
\hline & Contaminant on plants (except species transported by host/vector) \\
\hline & Parasites on animals \\
\hline & Parasites on plants \\
\hline & Seed contaminant \\
\hline & Timber trade \\
\hline & Transportation of habitat material (soil, vegetation...) \\
\hline \multirow{10}{*}{ 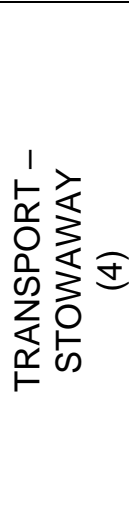 } & Angling/fishing aquaculture equipment \\
\hline & Container/bulk \\
\hline & Hitchhikers in or on plane \\
\hline & Hitchhikers on ship/boat \\
\hline & Machinery/equipment \\
\hline & People and their luggage/equipment \\
\hline & Ship/boat ballast water \\
\hline & Ship/boat hull fouling \\
\hline & Vehicles (car, trains...) \\
\hline & Other means of transpc \\
\hline
\end{tabular}




\begin{tabular}{|c|c|}
\hline & Interconnected waterways/basins/seas \\
\hline 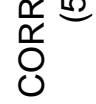 & Tunnels and land bridges \\
\hline 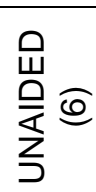 & $\begin{array}{l}\text { Natural dispersal across borders of alien species that have been introduced into the donor } \\
\text { region trough pathways } 1 \text { to } 5 \\
\text { Introduction without direct anthropogenic influence from an adjacent area where the Taxon } \\
\text { is alien }\end{array}$ \\
\hline
\end{tabular}




\section{Appendix S4: Invasion status according to Blackburn et al. (2011)}

Figure S4. The proposed unified framework for biological invasions according to Blackburn et al (2011).

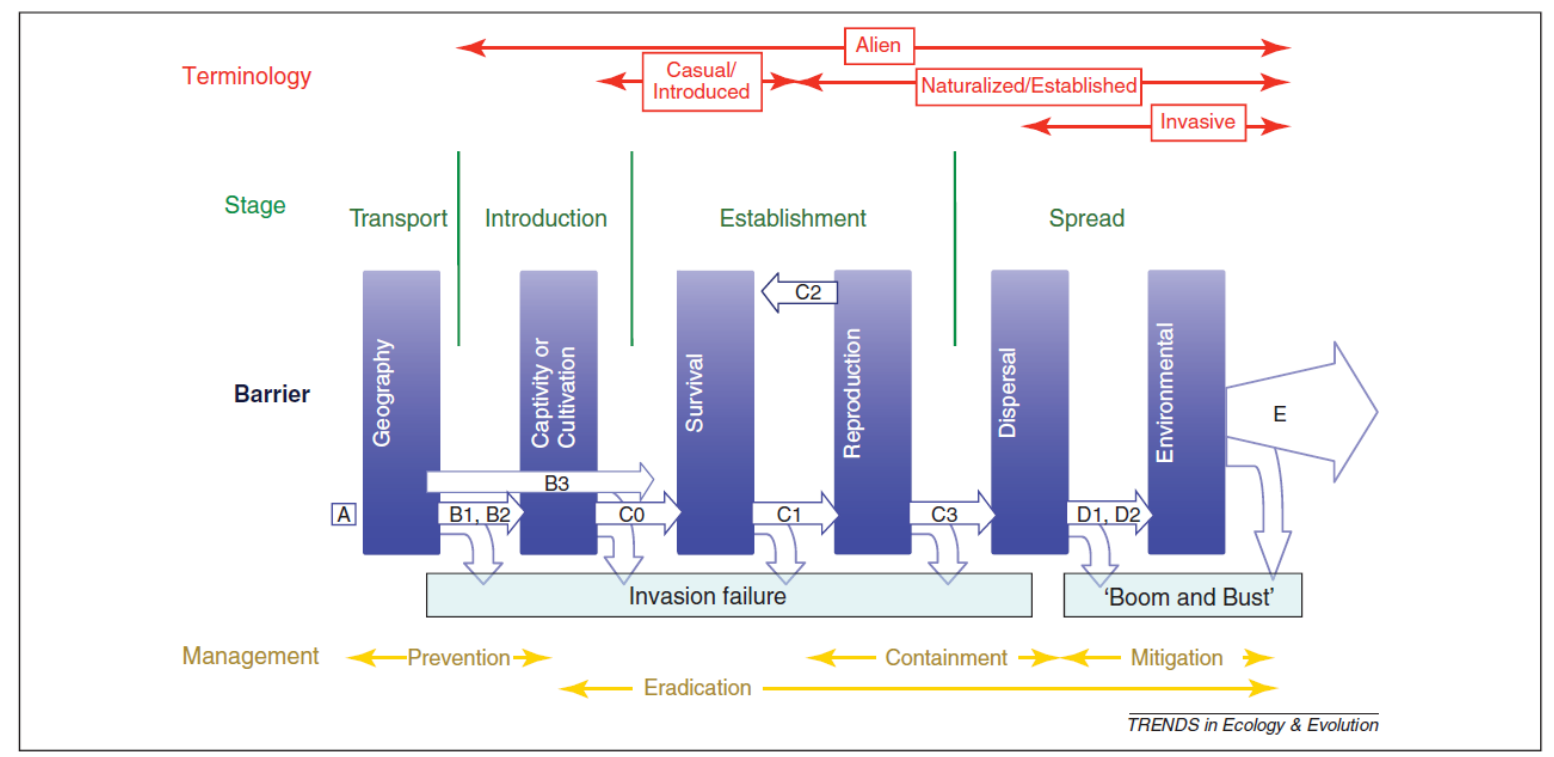

Table S4. A categorisation scheme for populations in the unified framework

\begin{tabular}{|c|c|}
\hline Category & Definition \\
\hline A & Not transported beyond limits of native range \\
\hline B1 & $\begin{array}{l}\text { Individuals transported beyond limits of native range, and in captivity or quarantine (i.e. individuals provided with conditions } \\
\text { suitable for them, but explicit measures of containment are in place) }\end{array}$ \\
\hline B2 & $\begin{array}{l}\text { Individuals transported beyond limits of native range, and in cultivation (i.e. individuals provided with conditions suitable } \\
\text { for them but explicit measures to prevent dispersal are limited at best) }\end{array}$ \\
\hline B3 & Individuals transported beyond limits of native range, and directly released into novel environment \\
\hline $\mathrm{CO}$ & $\begin{array}{l}\text { Individuals released into the wild (i.e. outside of captivity or cultivation) in location where introduced, but incapable of surviving } \\
\text { for a significant period }\end{array}$ \\
\hline C1 & Individuals surviving in the wild (i.e. outside of captivity or cultivation) in location where introduced, no reproduction \\
\hline $\mathrm{C} 2$ & Individuals surviving in the wild in location where introduced, reproduction occurring, but population not self-sustaining \\
\hline C3 & Individuals surviving in the wild in location where introduced, reproduction occurring, and population self-sustaining \\
\hline D1 & Self-sustaining population in the wild, with individuals surviving a significant distance from the original point of introduction \\
\hline D2 & $\begin{array}{l}\text { Self-sustaining population in the wild, with individuals surviving and reproducing a significant distance from the original } \\
\text { point of introduction }\end{array}$ \\
\hline $\mathrm{E}$ & $\begin{array}{l}\text { Fully invasive species, with individuals dispersing, surviving and reproducing at multiple sites across a greater or lesser } \\
\text { spectrum of habitats and extent of occurrence }\end{array}$ \\
\hline
\end{tabular}


Appendix S5. Results of combining probabilities to calculate the overall likelihood. This takes the upper bound of each probability interval. Note: anything where one element is extremely unlikely, is extremely unlikely.

\begin{tabular}{|l|l|l|l|}
\hline max (Lik1 \& Lik2) & max (Lik3 \& Lik4) & max (Lik5 \& Lik6) & Result \\
\hline Probable & Probable & Probable & Probable \\
\hline Probable & Probable & Fairly probable & Fairly probable \\
\hline Probable & Probable & Unlikely & Unlikely \\
\hline Probable & Probable & Very unlikely & Very unlikely \\
\hline Probable & Fairly probable & Fairly probable & Fairly probable \\
\hline Probable & Fairly probable & Unlikely & Unlikely \\
\hline Probable & Fairly probable & Very unlikely & Very unlikely \\
\hline Probable & Unlikely & Unlikely & Very unlikely \\
\hline Probable & Unlikely & Very unlikely & Very unlikely \\
\hline Probable & Very unlikely & Very unlikely & Very unlikely \\
\hline Fairly probable & Fairly probable & Fairly probable & Fairly probable \\
\hline Fairly probable & Fairly probable & Unlikely & Unlikely \\
\hline Fairly probable & Fairly probable & Very unlikely & Very unlikely \\
\hline Fairly probable & Unlikely & Unlikely & Very unlikely \\
\hline Fairly probable & Unlikely & Very unlikely & Very unlikely \\
\hline Fairly probable & Very unlikely & Very unlikely & Very unlikely \\
\hline Unlikely & Unlikely & Unlikely & Very unlikely \\
\hline Unlikely & Unlikely & Very unlikely & Very unlikely \\
\hline Unlikely & Very unlikely & Very unlikely & Extremely unlikely \\
\hline Very unlikely & Very unlikely & Very unlikely & Extremely unlikely \\
\hline
\end{tabular}




\section{Appendix S6: Summary sheet example}

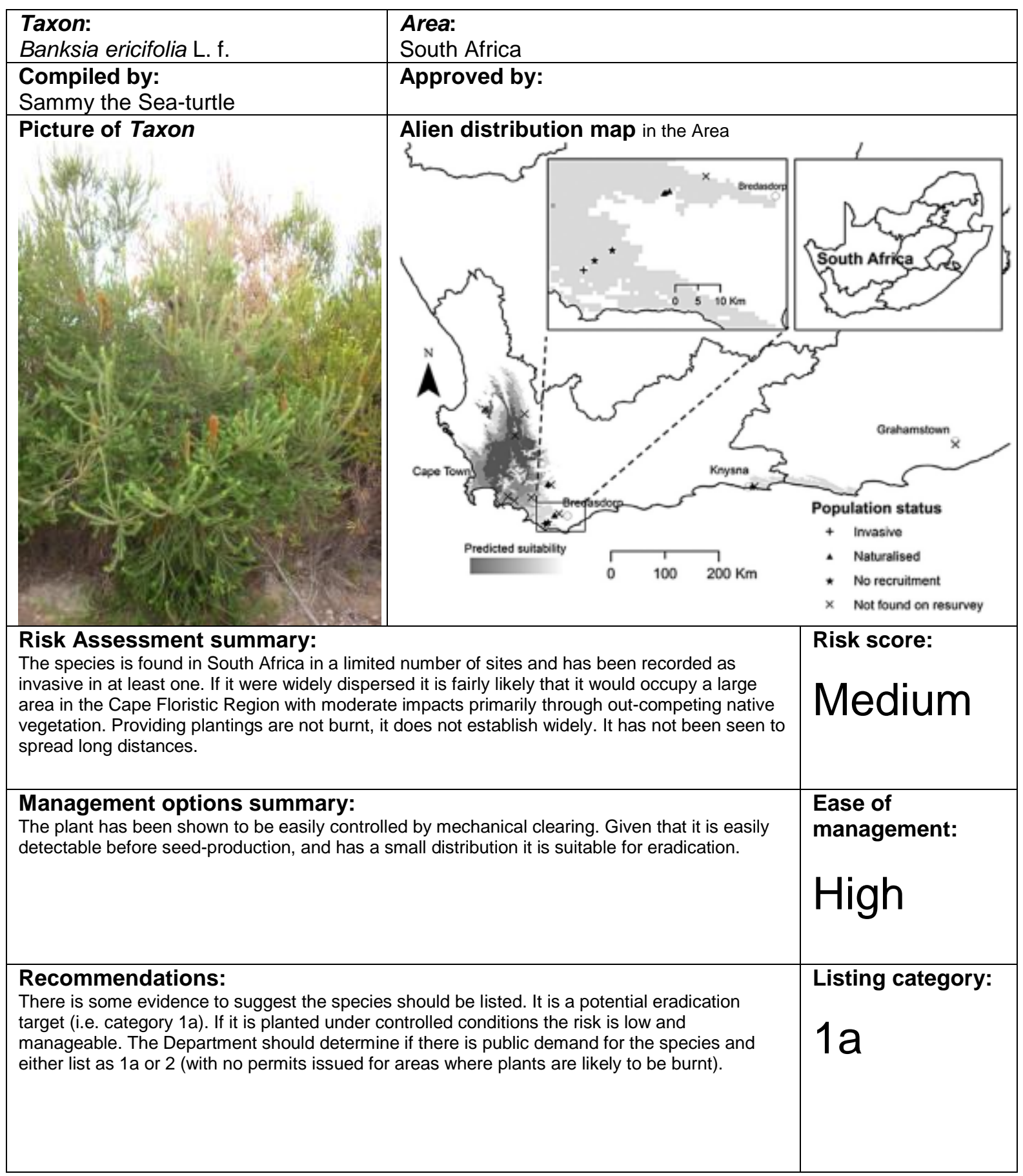


Appendix S7: A proposed framework for engaging stakeholders when developing management practices for alien and invasive species.

Figure taken from: Novoa, A., Shackleton, R., Canavan, S., Cybele, C., Davies, S.J., Dehnen-

Schmutz, K., Fried, J., Gaertner, M., Geerts, S., Griffiths, C.L. and Kaplan, H., 2018. A framework for engaging stakeholders on the management of alien species. Journal of Environmental Management, 205, 286-297.

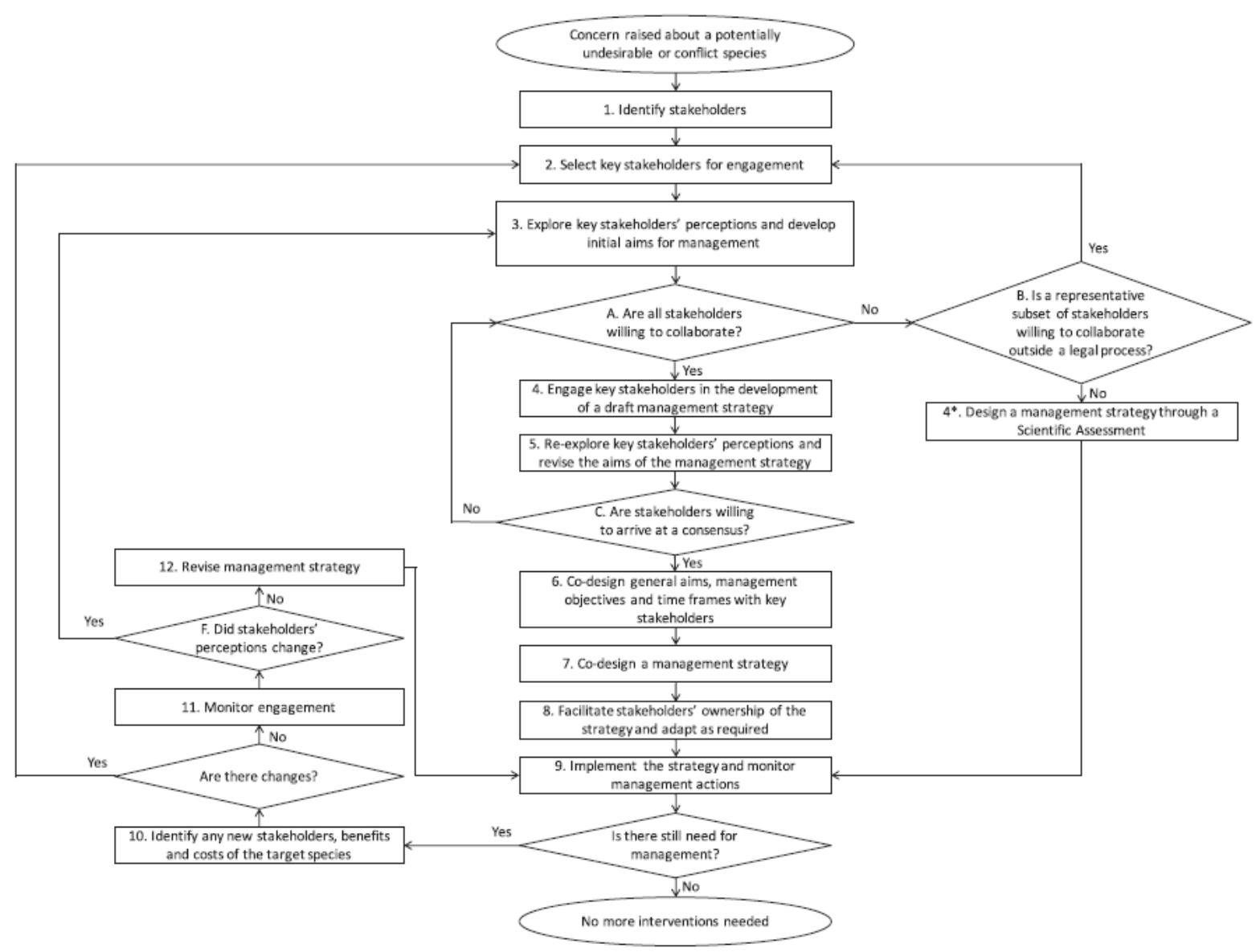

